\title{
Loss Underreporting and the Auditing Role of Bank Exams
}

March 15, 2002

Prepared for a symposium on

The Impact of Economic Slowdowns on Financial Institutions and Their Regulators

sponsored jointly by the

Federal Reserve Bank of Boston and the Journal of Financial Intermediation

April 17-19, 2002

Jeffery W. Gunther and Robert R. Moore

Federal Reserve Bank of Dallas

Abstract. Using a unique set of banking data containing both originally reported and subsequently revised financial variables, we study the incidence of adverse revisions to accounting statements. As might be expected, our findings indicate banks are more likely to underreport financial losses when their financial performance is substandard. In addition, we provide evidence that supervisory exams have an important role in uncovering financial problems and ensuring bank accounting statements reflect them. Specifically, our estimations point to a significant auditing effect, through which exams can lead to a restatement of financial results to reflect a greater degree of financial difficulty than originally reported. Interestingly, this auditing role of exams is evident not only for institutions previously identified as supervisory concerns, but also at highly rated banks, where financial problems are only just emerging. Because a banking downturn would increase not only the number of problem institutions requiring additional supervisory attention, but also the incidence of loss underreporting at highly rated banks, our findings stress the value of efforts to maintain or bolster the supervisory system's capacity to expand exam activity quickly and substantially.

Corresponding author: Jeffery W. Gunther, Financial Industry Studies Department, Federal Reserve Bank of Dallas, 2200 N. Pearl St., Dallas, TX 75201.

E-mail: jeffery.w.gunther@dal.frb.org.

JEL classification codes: G21, L51, and C25.

The views expressed are those of the authors and do not necessarily reflect the position of the Federal Reserve Bank of Dallas or the Federal Reserve System. We would like to thank, without implicating, two anonymous referees for their helpful comments and suggestions. 


\section{Introduction}

Without access to accurate information regarding the financial condition of individual banks, it would be difficult for regulatory and market discipline to circumscribe bank behavior effectively. Regulatory devices, such as prompt corrective action, together with market-based solutions to supervisory concerns, all depend on the ability of regulators and market participants to respond to changes in a bank's financial condition. However, there are good reasons to suspect a bank's true condition may be more readily apparent to its managers than to outsiders, including regulators and investors. As described by Townsend (1979), such an information asymmetry can significantly affect the relationship between insiders and outsiders.

Efforts to bridge this information gap have a long history. In the early 1800 s, some states required banks to file reports of condition with the governor or legislature, arguing the state was a shareholder in the banks and therefore entitled to the information (Robertson 1995). However, the reports contained only broad breakdowns of assets and liabilities and no information bank directors did not wish to disclose. In 1869, Congress empowered the Comptroller of the Currency to "call" for a full statement of condition from national banks several times a year. Supervisors since have made many changes to the resulting call report, but its purpose remains the same - to provide timely information regarding banks' financial condition.

The modern call report, or Report of Condition and Income, is filed quarterly by all banks and contains hundreds of accounting items that supervisors and private analysts use to characterize the financial condition of both individual banks and the banking sector. Because call reports are filed quarterly, whereas banks are typically examined about once every twelve to eighteen months, call report data potentially provide a more up-to-date picture of a bank's condition than supervisory exams alone. For this reason, both supervisors and private-sector analysts use call report data extensively in a variety of efforts to monitor banks' financial 
condition. It seems reasonable to suspect that the effectiveness of these monitoring efforts depends to a large degree on the accuracy of the reported information. If the call report data are subject to significant revisions, then the report's usefulness in tracking financial developments in real time might be compromised, as conjectured by Cole and Gunther (1998).

In addition, the Federal Deposit Insurance Corporation Improvement Act's prompt corrective action mandates tie the supervisory treatment of a bank to its financial condition, as portrayed in the call report. As a result, the degree to which a bank's supervisory treatment is aligned with its financial condition depends critically on the accuracy of the call report data.

How accurate, then, is the call report information? To gain insight into this and related issues, we analyze a unique set of data that includes the originally reported values of key financial variables, along with their values as reported at a later time, which reflect any revisions that occurred subsequent to the initial reports. Not surprisingly, a study of these revisions indicates banks are more likely to originally underreport financial losses when their financial performance is substandard. In addition, we provide evidence that supervisory exams have an important role in uncovering financial problems and ensuring bank accounting statements reflect them. Based on several different specifications, our results indicate exams often lead to a restatement of financial results to reflect a greater degree of financial difficulty than originally reported. In other words, exams effectively force bad news into the call report numbers. More remarkably, this auditing role of exams is evident not only for institutions previously identified as supervisory concerns, but also at highly rated banks, where financial problems are only just emerging.

We would like to note at the outset that in many cases exam findings may simply be reflected in a bank's current, or upcoming, call report, as opposed to revisions to previously reported figures. As a result, call report revisions alone clearly would not be expected to reflect 
the full extent of the auditing role of bank exams. Moreover, we are not able in this study to identify the factors influencing whether exam findings are reflected in upcoming call reports or revisions to previous reports. Nevertheless, the revisions provide a unique window through which to view the results of exam activity. Because the revisions can be calculated as simple differences between the original and revised reports, there is no need to estimate the impact of exam findings using deviations from expected, or normal, values.

We believe our empirical findings based on financial statement revisions have important supervisory implications. Our results indicate a banking downturn would likely work through two related channels to adversely impact the reliability of bank financial statements. First, as financial conditions deteriorated, we would expect, based on our results, an increase in the incidence of loss underreporting. Second, as supervisors spent additional time at the increasing number of troubled institutions, fewer supervisory resources might be available for routine exams. Because we find exams play an important role in uncovering financial misstatements, even at highly rated institutions, the reduction in supervisory resources available for routine exams could delay the correction of the rising number of underreported losses. The resulting deterioration in the quality of financial data could then impede the operation of supervisory and market discipline.

While today the banking sector appears to be holding up fairly well, there are signs of deterioration, implying the issues raised in our analysis may be relevant not only to future policy, but to the current situation as well. In Figure 1, we show for all U.S. commercial banks the mean value of the ratio of annual loan loss provisions to average assets. The burden of asset quality problems on bank profitability is nowhere near its peak of the mid-1980s, but the upward trend in this indicator is somewhat disturbing. The unique data used in our study are available only for the 1996-98 period, which as shown in Figure 1 was a relatively tranquil time for the banking 
sector. Nevertheless, we are able to identify a significant number of adverse revisions to financial statements. Given that financial conditions have deteriorated somewhat further since then, we expect that the auditing role of exams we document has become even more immediately relevant.

The remainder of this paper is organized as follows. The next section provides some institutional background regarding the potential relationship between the results of supervisory exams and revisions to financial statements. We then proceed to a description of the data we use, the presentation of our empirical results, and our conclusions.

\section{Background}

\subsection{Loan loss accounting}

Deterioration in loan portfolios typically has been the primary proximate cause of downturns in the banking sector. At the center of the banking industry's system to account for loan quality problems is the allowance for loan and lease losses (ALLL). Through provision for loan and lease losses, banks add funds to ALLL. These provisions are an expense item and reduce a bank's net income. The ALLL balance is subtracted from total loans, so loans on the balance sheet are reported net of ALLL. When loans are charged off, total loans are reduced by the amount of the losses, but the losses are charged against ALLL, leaving net loans unaffected. If a bank recovers some of the losses on loans previously charged off, the recoveries are added back to ALLL.

When a bank charges off a loan, the resulting loss does not affect reported net income, since the charge-off is against ALLL. Credit quality problems affect reported profitability when a bank incurs the provision expense, since the expense directly reduces net income. As a result, timely disclosure of information on credit quality and its impact on overall operating results depends on the degree to which provisions are made in anticipation of, or concurrent with, actual 
impairment in the loan portfolio. If adequate provisions are made only after the impairment occurs, profitability prior to the provisions is overstated.

One factor that might prompt banks to set an insufficient level of ALLL and provision expense involves regulatory or market-based penalties for a deterioration in financial condition. Risk-based capital requirements allow banks to count ALLL only in Tier 2 capital and only up to 1.25 percent of risk-weighted assets. By not making the necessary provisions, banks with assetquality problems can raise reported net income and retained earnings, thereby boosting Tier 1 capital and potentially avoiding the restrictions supervisors typically place on troubled banks. ${ }^{1}$

\subsection{Verifying the adequacy of $A L L L$}

Given the current institutional framework, which assigns supervisors a large role in the monitoring and disciplining of banks, the incentive to underreport provisions provides a particularly strong reason for supervisory exams. The Commercial Bank Examination Manual states that "the examiner's responsibility to determine the adequacy of a bank's ALLL is one of the most important functions of any examination" (Federal Reserve Board of Governors 1999). In verifying the adequacy of ALLL, examiners consider information obtained during the current and prior exams, loan quality trends and peer group data, processes for internal credit review, past-due and restructured loans, and economic conditions. If after considering these factors an examiner finds that a bank's ALLL is too low, the institution normally is required to increase its provision expense and raise ALLL to an appropriate level.

The supervisory assessment of ALLL occurs in the context of the rating system used in safety and soundness exams. Under the Uniform Financial Institutions Rating System adopted in 1979, a bank's overall, or composite, safety and soundness rating was derived from the on-site

\footnotetext{
${ }^{1}$ In addition, because the amount of Tier 2 capital is restricted to be no greater than the amount of Tier 1 capital, banks raising Tier 1 capital by making fewer provisions than necessary may in some cases be able to boost Tier 2 capital as well.
} 
evaluation and rating of five separate factors - capital adequacy (C), asset quality (A), management (M), earnings (E), and liquidity (L). This CAMEL rating was amended on January 1,1997 , to include a sixth component. The new $\mathrm{S}$ component focuses on sensitivity to market risk, such as the risk arising from changes in interest rates. The new $\mathrm{S}$ component was not expected to affect the composite ratings assigned to banks, and like the earlier CAMEL rating, the CAMELS overall rating has five levels: 1-basically sound in every respect; $2-$ fundamentally sound but with modest weaknesses; 3 -financial, operational, or compliance weaknesses that cause supervisory concern; 4-serious financial weaknesses that could impair future viability; and 5-critical financial weaknesses that render the probability of near-term failure extremely high. For simplicity, we apply the term CAMELS to both CAMEL and CAMELS ratings.

Currently, CAMELS ratings are assigned using the so-called "risk-focused" approach to exams, which as described below continues to give central importance to the assessment of ALLL. ${ }^{2}$ Under this approach, examiners target areas likely to pose the greatest risk to an examined institution. By targeting the areas of greatest risk, exams can promote safety and soundness more effectively, while imposing a lower burden on the examined institutions. The risk-focused approach relies on examiner discretion to determine the scope and emphasis of a particular exam, but the so-called "primary examination procedure modules" are normally included in every exam, two of which include facets addressing the adequacy of a bank's ALLL

\footnotetext{
${ }^{2}$ The Federal Reserve System began implementing a risk-focused approach in 1997. Spillenkothen (1997a) and Spillenkothen (1997b) describe the risk-focused framework for large complex institutions and community banks, respectively. As the risk-focused framework continues to evolve, the treatment of ALLL has retained its prominence. Spillenkothen (2001) provides an interagency (Federal Reserve, FDIC, OCC, and OTS) policy statement on ALLL methodologies and documentation; the policy statement reiterates the commitment of the banking agencies to assess the adequacy of ALLL in exams.
} 
and the reliability of published financial statements. ${ }^{3}$ The module on management and internal control evaluation instructs examiners to consider the accuracy of the bank's call report and to determine whether the bank has a history of call report amendments. Moreover, this module also instructs examiners to assess whether the bank is monitoring risk effectively; included in this assessment is a consideration of the adequacy of ALLL. Related assessments are also prominent in the module for evaluating loan portfolio management and review. Two of the twelve primary steps in this module involve ALLL; one step evaluates the method using in establishing the ALLL balance, while the other focuses on the adequacy of that balance. One of the points of evaluation deals with whether controls exist to ensure compliance with accounting standards. In addition, if the primary analysis of loan portfolio management and review indicates risks are not adequately managed, additional analyses of ALLL are triggered.

\subsection{Previous research on exams and ALLL}

Several studies support the view that troubled banks often have insufficient ALLL and that exams are important in helping correct the problem. The General Accounting Office (1990, 1991) finds troubled or failing banks frequently have insufficient ALLL. Similarly, Berger, King, and O'Brien (1991) discuss the potential for insufficient ALLL, particularly when a bank has not been examined recently. Gilbert (1993) finds abnormally large reductions in capital ratios occur when supervisors downgrade troubled banks. Dahl, O’Keefe, and Hanweck (1998) conclude that exams influence the recognition of losses on commercial and industrial loans. And Curry, O'Keefe, Coburn, and Montgomery (1999) find banks that supervisors have downgraded or subjected to regulatory enforcement actions increase their provision expense.

\footnotetext{
${ }^{3}$ The parlance used in this discussion is that for community banks. While large, complex institutions are discussed using different terms, their risk-focused examinations also include a review of ALLL as a basic component.
} 
Setting provisions requires detailed knowledge about a bank's loan portfolio. Bank managers are more likely than outsiders to have such detailed knowledge. Through exams, supervisors may gain knowledge about the adequacy of ALLL. If an exam aligns provision expense and ALLL with credit quality, it may facilitate the public communication of important bank-specific information and thereby enhance banking system transparency. Consistent with this view, Docking, Hirschey, and Jones (1997) find a bank's announcement of loan-loss provisions adversely affects both that bank's stock price and sometimes the stock price of other banks as well. Berger and Davies (1998) provide evidence that quarterly financial statements are a conduit for transmitting exam findings to financial markets. And Flannery and Houston (1999) find exams affect the relationship between a bank holding company's market and book value, possibly reflecting the improved accuracy of financial statements following an exam or a certification effect whereby exams serve as a stamp of approval on published financial statements.

Other researchers have reached a different conclusion, however, arguing essentially that outsiders can see through a bank's loan-loss accounting and discern the true quality of its loans, even if provisions and ALLL are lower than necessary. Bruner and Simms (1987), Musumeci and Sinkey (1990a, 1990b) and Beaver and Engel (1996) suggest investors effectively estimate the extent of the deterioration in bank loan portfolios. If without substantial cost outsiders can indeed accurately estimate losses in a bank's loan portfolio on the basis of other information, the benefits of exams in assessing loan quality and the sufficiency of ALLL may be limited mostly to the supervisory process itself, as opposed to the promotion of financial transparency in general. 


\section{Data}

\subsection{Revisions and sample design}

The annual data this study uses are limited to commercial banks for the period from 1996 through 1998. Banks less than four years old are excluded, since young banks typically exhibit unique financial characteristics and are not directly comparable to more mature banks. The resulting sample contains 25,514 end-of-year call reports.

The originally reported data are from files transmitted from the Federal Reserve Board, seventy to eighty days following the report dates. The revised data are for the same report dates but were transmitted from the Board in May 2000. Any differences between the original data and the data obtained in May reflect revisions made sometime after the data were published as "final," which typically occurs about sixty-five days after the report date.

\subsection{Variables}

We analyze twelve financial ratios corresponding to the main categories of financial factors considered in supervisory exams of financial safety and soundness. Balance-sheet variables are scaled by end-of-period gross assets, while income-statement variables are expressed relative to average assets for the period. It is not difficult to envision additional measures relevant to the categories we consider, but some degree of parsimony is necessary to maintain tractability. In any event, alternative measures under a particular category tend to be highly correlated.

In addition to analyzing revisions to each of the twelve financial ratios we consider, we also use these ratios to assess the degree to which banks with financial problems may have a relatively high incidence of adverse financial statement revisions, especially upward revisions to provision expense. Such revisions provide a convenient focal point for the analysis, given the central role of loan loss provisions and ALLL in accounting for asset quality problems. To the 
extent that the financial ratios can be used to identify banks that are the most likely to require additional provisions, it may be in the interest of supervisors to devote special attention to these banks, even to the point of moving up a scheduled exam visit.

Total equity capital (CAPITAL) is a measure of capital adequacy. High values for this variable indicate financial strength and should reduce the chances of an upward revision to provision expense. A similar effect should be associated with high levels of loan loss reserves (RESERVES), all else equal. However, reserves represent coverage for loan losses that have not yet been taken but are nevertheless expected and embedded in the current portfolio. As a result, we would expect a negative effect of reserves on upward revisions to provision expense only to the extent that the embedded losses themselves are fully represented by other variables included in the regressions. Otherwise, by reflecting the presence of problem assets, RESERVES could be positively associated with upward revisions to provision expense.

Asset quality problems are captured through six variables, each of which is expected to increase the chances of an upward revision to provision expense. Problem assets themselves are represented by loans past due 90 days or more and still accruing (PAST-DUE 90), nonaccrual loans (NONACCRUAL), and other real estate owned (OTHER REAL ESTATE), which consists primarily of foreclosed real estate. ${ }^{4}$ In addition, net loan charge-offs (CHARGE-OFFS) and provision for loan losses (PROVISIONS) are also included. The final variable included to capture asset quality problems is income earned on loans but not collected (INC NOT COLLECTED). This latter variable represents interest payments that are still accruing, even though they have not been collected.

\footnotetext{
${ }^{4}$ Loans are reported in nonaccrual status if they are maintained on a cash basis because of deterioration in the financial condition of the borrower, payment in full of principal or interest is not expected, or principal or interest has been in default for 90 days or more. An exception to this last condition occurs if a loan is both well secured and in the process of collection.
} 
Measures of earnings and liquidity complete our list of financial ratios. Earnings are represented by net income (RETURN ON ASSETS) and as a signal of financial strength are expected to reduce the chances of an upward revision to provision expense. As a measure of liquidity, investment securities (SECURITIES) should reduce the chances of an upward revision to provision expense, as should high holdings of cash and net fed funds sold $(C A S H) .^{5}$ In contrast, by subjecting a bank to higher costs and a potentially less stable funding base, a high reliance on large CDs ( $L A R G E C D S$ ) might have the opposite effect on revisions to provision expense.

\section{Results}

While we focus on exam driven revisions, not all of the call report revisions we observe are attributable to exams. In fact, other types of revisions are also likely to occur, reflecting the combined effect of a host of influences, such as random error, routine data checks, or the findings of internal or external auditors. Unfortunately, there is no indicator to identify for us the ultimate source of each revision. We are left then with the challenge of identifying statistically the degree to which the revisions are associated with exams.

\subsection{Exams and the incidence of revisions}

Table 1 divides the observations into five groups corresponding to a bank's exam status in the year immediately following a year-end call report date. The first group contains banks for which an exam was opened in the first quarter, the second group contains banks not examined until the second quarter, and so on for the third and fourth groups. The fifth group contains banks that were not examined at all in the year following the call report date. For each financial ratio and each of the five groups, Table 1 shows the percentage of observations for which a

\footnotetext{
${ }^{5}$ Investment securities tend to be more liquid than loans. In addition, they typically carry lower credit risk. Given the strong negative correlation that exists between the holdings of these two interest-bearing assets, we include only one in the analysis.
} 
positive revision occurred and also the percentage with a negative revision. Here, revisions are identified based on changes to the numerator of each financial ratio, irrespective of whether the denominator (assets) was also revised.

The statistics on the incidence of revisions suggest a significant number resulted from exam findings. Looking first at the results for the capital ratio (CAPITAL), 6.3 percent of the banks examined in the first quarter revised their previous reported year-end level of capital downward. The incidence of downward revisions then declines for the groups corresponding to more distant exams, falling to 2.8 percent for banks that were not examined at all. In contrast, the incidence of positive revisions to capital is relatively low and constant across the five groups of banks. These patterns conform closely to the idea that because examiners focus on downside risk, they are more prone to require call report revisions when exam findings are adverse. The data also are consistent with the intuitive notion that examiners would be more likely to require revisions to relatively recent call reports, rather than call reports filed in the distant past. A sign test indicates the observed differences between the incidence of positive and negative revisions to capital are statistically significant. In addition, a Pearson chi-square test statistic rejects the null hypothesis of no association between the incidence of revisions (positive, negative, or none) and the incidence of exams (first, second, third, or fourth quarter, or none).

The pattern of adverse revisions to previous year-end capital levels, especially at banks examined near the beginning of the year, is apparent for several of the other variables as well. As shown in Table 1, revisions to loan loss reserves (RESERVES) tend to be positive, consistent with the view that examiners sometimes find the level of reserves to be inadequate. Similarly, loan charge-offs (CHARGE-OFFS) and provision for loan losses (PROVISIONS) also tend to be revised upward, while net income (RETURN ON ASSETS) is restated at lower levels. Finally, the level of interest payments accrued but not collected (INC NOT COLLECTED) and past-due 
loans (PAST-DUE 90) tend to fall, possibly reflecting the downgrade of past-due loans to nonaccrual status.

In a manner similar to the procedure used for Table 1, the same five groups of observations are analyzed in Table 2, but now revisions are identified based on all changes to the financial ratios, whether they resulted from revisions to the numerator, denominator, or both. While the incidence of revisions is now higher, the general pattern of revisions observed in Table 1 is repeated in Table 2 for CAPITAL, RESERVES, CHARGE-OFFS, PROVISIONS, and RETURN ON ASSETS. However, unlike in Table 1, investment securities (SECURITIES), cash and net fed funds sold $(C A S H)$, and holdings of large CDs ( $L A R G E C D s)$ now tend to show positive revisions for banks examined in the first quarter, reflecting the preponderance of negative revisions to gross assets for this group of banks.

If exams lead banks to correct the underreporting of financial losses, then adverse revisions to financial statements might be especially prevalent in cases where examiners find that a bank's financial condition has deteriorated to a sufficient degree to warrant a downgrade in the bank's safety and soundness rating. In this regard, the incidence of revisions at downgraded banks provides further evidence that a significant number were the result of exam findings, as the pattern of adverse revisions shown in Tables 1 and 2 is even more apparent when the examined banks are grouped according to whether a supervisory downgrade occurred.

In Tables 3 and 4, the first group contains banks for which a downgrade occurred through an exam opened in the first quarter, the second group contains banks downgraded in the second quarter, and so on for the third and fourth groups. The fifth group contains banks that were examined in the year following the call report date, but not downgraded. Among the banks downgraded in the first quarter, 18.2 percent revised their previous reported year-end level of capital downward, as shown in Table 3. This high rate of revision falls to 2.9 percent for banks 
downgraded in the fourth quarter and 4.2 percent for the banks that were examined, but not downgraded. The results in Table 3 for revisions to the numerators of RESERVES, PAST-DUE 90, CHARGE-OFFS, PROVISIONS, INC NOT COLLECTED, and RETURN ON ASSETS also exhibit an exaggerated version of the general patterns shown in Table 1, strongly suggesting that adverse exam findings are responsible for a significant number of the revisions observed in the call report numbers. Similar results are reported in Table 4, where revisions are identified for the downgraded banks based on any changes to the financial ratios, whether they resulted from revisions to the numerator, denominator, or both.

The finding that adverse revisions to financial statements are associated with exam findings points to a role for exams in uncovering financial problems and ensuring bank accounting statements reflect them. An important aspect of the analysis is that the period from which the financial statements are drawn, 1996-98, was a relatively tranquil time for the banking sector. Because financial problems were few, any need for increases in provisions could be expected to have been low. The relatively benign operating environment most likely helped hold to a minimum the number of data revisions in our sample, as the vast majority of exams merely confirmed that individual banks remained financially sound. We would expect both the percentage of banks with upward revisions to provision expense and the difference in the incidence of these revisions between examined and unexamined banks to climb during a banking downturn.

\subsection{Controlling for financial condition}

If exam activity happens to be centered on banks with financial problems, then the correlation observed in Tables 1 through 4 between exam activity and call report revisions might simply reflect a greater tendency for troubled banks to revise their financial statements, as opposed to a direct revision effect of exams themselves. However, to the extent that the various 
financial ratios we have examined effectively capture the financial condition of individual banks, then by using a regression to hold these variables constant, we can eliminate the associated omitted variables bias. Toward this end, we now regress the incidence of revisions on not only indicators for exam activity, but also the twelve financial ratios analyzed in Tables $1-4$, the $\log$ of total assets $(S I Z E)$, and the rating assigned in a bank's most recent safety and soundness exam (CAMELS-1).

Rather than conducting separate regression analyses for revisions to each of the financial ratios, we focus on upward revisions to provision expense. As discussed earlier, loan loss provisions may play a key role in conveying to market participants timely information regarding any deterioration in asset quality, and the need for additions to ALLL is of primary supervisory concern. Moreover, the results in Tables 1 through 4 document both a high incidence of upward revisions to provision expense and a significant degree of correlation with exam activity. Reflecting these considerations, the dependent variable, REVISION, is equal to one if provision expense was revised upward, and zero otherwise.

In preparation for the regression results, Table 5 shows the variable means for banks categorized according to whether they revised their provision expense upward $(R E V I S I O N=1)$. Based on these comparisons, banks that revised differ substantially from those that did not. With the exception of SIZE and RESERVES, each of the variables is correlated with the incidence of revisions, using both the originally reported and revised data. There is no evidence of a location shift in the distribution of SIZE between banks that revised and those that did not. Based on the revised data only, the incidence of revisions is associated with high RESERVES. With regard to the other variables, revising banks tend to be financially weaker than non-revising banks (worse CAMELS-1, lower CAPITAL, higher PAST-DUE 90, NONACCRUAL, OTHER REAL ESTATE, CHARGE-OFFS, PROVISIONS, INC NOT COLLECTED, lower ROA and SECURITIES, and 
higher $L A R G E C D s)$. An apparent exception occurs with $C A S H$, which is higher for revising banks.

In Table 6, we report the ordinary least-squares and probit regression results for the incidence of upward revisions to provision expense. Two versions of each regression are estimated, one whether the explanatory variables are based on the originally reported data and one using the revised data. In addition to the covariates shown in Table 5, four indicators of exam activity are included in the regressions. EXAM1 is a binary indicator for whether a bank's first exam in the year immediately following a year-end call report occurred in the first quarter, $E X A M 2$ is a binary indicator for banks examined in the second quarter, and so on for $E X A M 3$ and EXAM4. In explaining upward revisions to provision expense, we use the occurrence of an exam, rather than that of a supervisory downgrade, as our measure of exam activity. Because downgrades reflect exam findings, they may be as much the result of financial statement revisions as the other way around. In this way, we view revisions and downgrades as being in many cases the joint result of exams.

While there are some differences between the estimates based on the originally reported data and those based on revised data, overall the results indicate banks are more likely to originally underreport financial losses, as suggested by subsequent upward revisions to provision expense, when their financial condition is substandard. In at least two of the four regressions, the probability of revision is associated with worse CAMELS-1, lower RESERVES, higher PASTDUE 90, NONACCRUAL, OTHER REAL ESTATE, and PROVISIONS, lower ROA and SECURITIES, and higher LARGE CDs.

Of particular interest are the results for the variables based on exam activity. The coefficient on EXAM1 is positive and significant in each of the four regressions, and EXAM2 is 
positive and significant in three cases. ${ }^{6}$ These findings, after controlling for the financial condition of individual banks, point to an auditing role for exams in leading to the restatement of financial results to reflect a greater degree of financial difficulty than originally reported.

\subsection{Instrumental variables}

The regression analysis in Table 6 eliminates the potential for omitted variables bias only to the extent that our list of explanatory variables includes all the factors that help determine revisions and exams, which is admittedly unlikely. To control more fully for omitted variables bias, we now consider explicitly the potential determinants of exam activity. More specifically, we attempt to identify an instrument which is correlated with exams, but otherwise unrelated to revisions. To be valid, the instrument must be uncorrelated with any relevant variables that have been omitted from the revisions regression and the regression error. Such an instrument would allow us to use the exogenous component of exam activity to obtain a pure estimate of the relationship between exams and revisions.

In the instrumental variables analysis, we focus on exam activity in the first two quarters of the year immediately following a year-end call report, as suggested by the regression results in Table 6, which point to these exams as having a potentially significant effect on revisions to the year-end data. The first stage then involves estimating a linear regression for EXAM, a binary indicator for whether a bank's first exam in the year immediately following a year-end call report occurred in the first half. A linear specification for the first-stage regression is motivated by the fact that two-stage least squares (2SLS) estimates based on a linear probability model are

\footnotetext{
${ }^{6}$ We also interact time (quarters) since the last exam with a single indicator variable for exams conducted in the first and second quarters, to see if a relatively long length of time since the last exam might heighten the tendency for the current exam to result in revisions. However, this interaction term is insignificant in both OLS regressions and the probit regression based on originally reported data. In the probit regression using revised data, this term possesses the expected positive sign and is significant, but only at the 5-percent level. The other results from the regression are unaffected by the interaction term. Overall, we are unable to find convincing evidence for
} 
consistent whether or not the first-stage conditional expectation function is actually linear, whereas a nonlinear specification for the first stage (such as logit or probit) generates consistent second-stage estimates only if the nonlinear specification chosen for the first stage is exactly correct [see Angrist (2001) and Angrist and Krueger (2001)].

Regarding the second stage, even if the underlying relationship is nonlinear, linear instrumental variables estimates generally are successful in identifying average effects, and the 2SLS estimates of such effects are typically similar to the estimates produced by more general estimation strategies. Angrist (1991) shows that 2SLS estimation produces results similar to the average treatment effect estimated in a bivariate probit model. Evans, Farrelly, and Montgomery (1999) provide a nice example of the linear instrumental variables technique when the outcome of interest and the potentially endogenous variable are both discrete, as is the case here.

To obtain consistent estimates of the impact of exams on financial statement revisions in the 2SLS regressions, we must possess a variable that induces revisions only through the occurrence of exams. In this regard, the supervisory agencies operate under frequency guidelines dictating that banks be examined at least once every 18 months. More specifically, the guidelines allow an 18-month exam cycle for 1- and 2-rated banks with total assets less than or equal to $\$ 250$ million, while other banks are required to be examined at least once every 12 months (Board of Governors 2000). These guidelines have a substantial influence on the timing of exams, but absence the actual occurrence of an exam, where a bank stands in its exam cycle would not be expected to influence whether or not the bank would revise a prior call report. We use as an instrument the number of quarters left in a bank's exam cycle, as of the call report date (FREQUENCY).

the notion that an exam conducted following a relatively lengthy period of no exam activity is more likely to result in revisions. 
Table 7 shows the variable means for banks according to whether or not they were examined in the first two quarters of the year immediately following a year-end call report $(E X A M=1)$, using both original and revised values. The occurrence of an exam is associated with a low amount of time remaining in a bank's exam cycle (FREQUENCY). Examined banks also have worse (higher) values of CAMELS-1 than unexamined banks, suggesting examiners direct increased attention to known supervisory problems. Also, in several cases, the differences in means suggest exam activity is directed at financially troubled banks. Using either the original or revised data, exams are associated with high PAST-DUE 90, NONACCRUAL, PROVISIONS, and INC NOT COLLECTED, and low RETURN ON ASSETS.

The 2SLS regression results are shown in Table 8 . The first two columns contain the results for $E X A M$, using original and revised data, respectively. The less time remaining in the exam frequency guidelines, the more likely is an exam, as indicated by the negative and highly significant estimated effect of FREQUENCY. In addition, EXAM is associated with a small asset base $(S I Z E)$, a poor supervisory rating $(C A M E L S-1)$, and low liquidity $(C A S H)$. The results also indicate high levels of foreclosed real estate reduce the chances of an exam. This unexpected finding may reflect a tendency for holdings of foreclosed real estate to remain relatively high for a significant length of time after a bank has recovered from a round of asset quality difficulties.

The results for REVISION are shown in the third and fourth columns of Table 8. Most importantly, the coefficient on EXAM is positive and significant, using either original or revised data. The 2SLS estimates for the remaining variables are virtually identical to the singleequation estimates presented earlier in Table 6 . The finding of a significant auditing role for exams in leading to the restatement of financial results to reflect a greater degree of financial 
difficulty than originally reported is robust with respect to all our attempts to control for omitted variables bias. $^{7}$

\subsection{Financial significance of revisions}

While we have found substantial evidence that exams are effective in uncovering financial problems and ensuring financial statements reflect them, are the revisions financially significant? To help answer this question, Table 9 shows the means of the twelve financial ratios for banks that were examined in the first half of the year $(E X A M=1)$ and revised their provision expense upward (REVISION=1), using both the originally reported and subsequently revised data. On average, the level of PROVISIONS rose over 60 basis points. As would be expected, RETURN ON ASSETS and CAPITAL were also revised at most of these banks, both falling over 50 basis points, on average..$^{8}$

From a safety and soundness standpoint, these changes appear to be significant. In further support of this view, in another study [Gunther and Moore (forthcoming)] we find that the relationship between accounting data and safety and soundness ratings is significantly stronger for the revised data than for the data as originally reported. The originally reported data

${ }^{7}$ To determine whether pooling affects the results, we also estimate the 2SLS regressions separately for each of the three year-end call report dates included in the analysis. The resulting coefficient estimates for EXAM are positive and significant in each of the three years. The estimates and their standard errors are as follows: for 1996, the original data yield $.0142(.0045)$ and the revised data give $.0132(.0044)$; for 1997, the original data give $.0150(.0044)$ and the revised $.0138(.0042)$; for 1998, the corresponding estimates are $.0209(.0043)$ and .0196 (.0042).

${ }^{8}$ It may be useful at this point to highlight the fact that it is not necessary for the revisions observed for two related variables to match, or add up. Some remaining differences may reflect the use of different denominators for ratios using balance-sheet versus income-statement variables in the numerator. In addition, other variables may also have been revised. To illustrate this latter case, as indicated in Table 9 there are seven observations for which a bank was examined and provision expense was revised upward, although capital was not revised. Taken in isolation, this would seem to violate the accounting constraint whereby higher provision expense would reduce net income, retained earnings, and ultimately capital. However, for these seven seemingly anomalous cases, additional variables were revised, resulting in no change to net income and hence no change in capital (or gross assets). Specifically, five of the seven observations had revisions to noninterest expense that exactly offset the revision to provision expense. One of the seven had an increase in noninterest income that exactly offset the increase in provision expense. Finally, another had revisions to net interest income, noninterest income, and noninterest expense that together exactly offset the revision to provision expense. Similar considerations apply to other 
often understate emerging financial weaknesses, to the extent that the capacity of the original data to distinguish problem from nonproblem banks, as viewed from a supervisory perspective, is compromised.

The magnitude of the revisions is also apparent in a comparison of the distribution of RETURN ON ASSETS, before and after revisions. In Figure 2, we show the proportion of observations within 50 basis points of each value of profitability for banks with $E X A M=1$ and REVISION $=1$, first using the originally reported data and then using the revised data. For purposes of further comparison, we also show the same distribution for all observations, using the revised data. As shown in Figure 2, banks that were examined and revised provision expense upward were not as profitable as banks on average, even before revising provisions to reflect the actual extent of their financial difficulty. However, once the additional provisions were made, the banks' profitably was reduced further, and by an order of magnitude similar to their original shortfall.

\subsection{Exams and revisions at highly rated banks}

The results above document the role of exams in identifying financial losses and ensuring that bank accounting statements reflect them. In this section, we estimate the 2SLS regressions again, except this time we obtain separate estimates for nonproblem banks $(C A M E L S-1=1$ or 2$)$ and problem banks $(C A M E L S-1=3,4$, or 5). There are 24,519 observations for the nonproblem banks and 995 problem-bank observations.

Our objective is to determine whether the auditing role of exams is important only for banks with known problems, or whether exam-based revisions to financial statements also occur at highly rated institutions. Banks with a composite rating of 4 or 5 are obviously viewed as

apparent exceptions, such as the four cases where a bank was examined and revised provision expense upward, but did not revise reserves. 
problem banks, and 3-rated banks are sometimes referred to as problems as well. Recall that a 2rating is for banks that are fundamentally sound but with modest weaknesses, whereas a 3-rating corresponds to financial, operational, or compliance weaknesses that cause supervisory concern. In this sense, a rating of 3 brings a bank into transitional status, from which point further deterioration is not uncommon. Generally speaking, once a bank moves to a 3-rating, supervisors tend to increase direct inspection efforts relative to off-site efforts based on call report data. This tendency is embodied in the exam frequency guidelines themselves, which allow a longer exam cycle for 1- and 2-rated banks, as discussed earlier. As a result, a finding of significant accounting revisions at 1- and 2-rated banks would have important supervisory implications, since supervisors typically rely heavily on the accounting numbers in monitoring changes in the financial condition of highly rated banks. In other words, such a finding would indicate the original call report data may be unreliable at the point where they are relied upon the most.

The results in Table 10 for nonproblem banks are broadly similar to those for the full sample. Exams and indicators of financial weakness are associated with a heightened probability of upward revisions to provision expense. These findings are important because they indicate exams uncover accounting misstatements at banks not already formally identified as problems. Nevertheless, the financially weakest of the highly rated banks are the most likely to require revisions.

Table 11 shows the regression results for banks rated 3,4 , or 5 at their most recent prior exam. For these banks, EXAM is significant only in the model estimated using revised data. However, significance levels in general are lower for the subset of banks previous identified as supervisory problems, most likely reflecting, at least in part, the smaller sample size. 


\section{Conclusion}

Evidence from a unique set of data containing both originally reported and subsequently revised financial variables indicates banks are more likely to originally underreport financial losses when their financial performance is substandard. In addition, our analysis documents an important role for supervisory exams in uncovering financial problems and ensuring bank accounting statements reflect them.

Interestingly, the auditing role of exams is evident not only for institutions previously identified as supervisory concerns, but actually is also apparent at highly rated banks, where financial problems are only just emerging. This finding highlights the risk of relying on reported financial statements in monitoring changes in the financial condition of 1- and 2-rated banks. Partially mitigating this risk are the results showing that indicators of financial weakness can be used to identify banks that are the most likely to require additional provisions. Based on this finding, it may be in the interest of supervisors to devote special attention to the highly rated banks that appear the weakest based on call report data, even to the point of moving up a scheduled exam visit.

The primary implication of our findings that we wish to emphasize concerns the efficacy of the supervisory process during a banking downturn. Our results indicate the incidence of loss underreporting would increase as financial conditions worsened. Because an increasing number of troubled institutions would demand additional supervisory attention, fewer resources might then be left for routine exams. Based on our finding that exams play an important role in uncovering financial misstatements, even at highly rated institutions, we would expect any reduction in supervisory resources available for routine exams to delay the correction of the rising number of underreported losses. The resulting deterioration in the quality of financial data could then impede the operation of supervisory and market discipline. These considerations 
highlight the value of efforts to maintain or bolster the supervisory system's capacity to expand exam activity quickly and substantially in the event of a banking downturn. 


\section{References}

Angrist, Joshua D. (2001), "Estimation of Limited Dependent Variable Models with Dummy Endogenous Regressors: Simple Strategies for Empirical Practice," Journal of Business and Economic Statistics 19 (January): 2-16.

Angrist, Joshua D., and Alan B. Krueger (2001), "Instrumental Variables and the Search for Identification: From Supply and Demand to Natural Experiments," Journal of Economic Perspectives 15 (Fall): 69-85.

Beaver, William H., and Ellen E. Engel (1996), "Discretionary Behavior with Respect to Allowances for Loan Losses and the Behavior of Security Prices," Journal of Accounting and Economics 22 (August-December): 177-206.

Berger, Allen N., and Sally M. Davies (1998), "The Information Content of Bank Exams," Journal of Financial Services Research 14 (October): 117-44.

Berger, Allen N., Kathleen Kuester King, and James M. O’Brien (1991), “The Limitations of Market Value Accounting and a More Realistic Alternative, Journal of Banking and Finance 15 (September): 753-83.

Bruner, Robert F., and John M. Simms Jr. (1987), "The International Debt Crisis and Bank Security Returns in 1982," Journal of Money, Credit, and Banking 19 (February): 46-55.

Cole, Rebel A., and Jeffery W. Gunther (1998), "Predicting Bank Failures: A Comparison of Onand Off-Site Monitoring Systems, Journal of Financial Services Research 13 (April): 103-17.

Curry, Timothy J., John P. O'Keefe, Jane Coburn, and Lynne Montgomery (1999), "Financially Distressed Banks: How Effective Are Enforcement Actions in the Supervisory Process?" FDIC Banking Review 12 (No. 2): 1-18.

Dahl, Drew, John P. O'Keefe, and Gerald A. Hanweck (1998), "The Influence of Examiners and Auditors on Loan-Loss Recognition," FDIC Banking Review 11 (No. 4): 10-25.

Docking, Diane Scott, Mark Hirschey, and Elaine Jones (1997), "Information and Contagion Effects of Bank Loan-Loss Reserve Announcements," Journal of Financial Economics 43 (February): 219-39.

Evans, William N., Matthew C. Farrelly, and Edward Montgomery (1999), "Do Workplace Smoking Bans Reduce Smoking?” American Economic Review 89 (September): 728-47.

Federal Reserve Board of Governors (1994), "Internal Control," Commercial Bank Examination Manual, November.

(1999), "Allowance for Loan and Lease Losses," Commercial Bank Examination Manual, November. 
(2000), "Examination Strategy and Risk-Focused Examinations," Commercial Bank Examination Manual, May.

Flannery, Mark J., and Joel F. Houston (1999), "The Value of a Government Monitor for U.S. Banking Firms," Journal of Money, Credit, and Banking 31 (February): 14-34.

General Accounting Office (1990), "Bank Insurance Fund: Additional Reserves and Reforms Needed to Strengthen the Fund," GAO/AFMD-90-100, September.

(1991), "Failed Banks: Accounting and Auditing Reforms Urgently Needed," GAO/AFMD-91-43, April.

Gilbert, R. Alton (1993), "Implications of Annual Examinations for the Bank Insurance Fund," Federal Reserve Bank of St. Louis Review 75 (January/February): 35-52.

Gunther, Jeffery W., and Robert R. Moore (forthcoming), "Early Warning Models in Real Time," Journal of Banking and Finance.

Musumeci, James J., and Joseph F. Sinkey Jr. (1990a), “The International Debt Crisis, Investor Contagion, and Bank Security Returns in 1987: The Brazilian Experience," Journal of Money, Credit, and Banking 22 (May): 209-20.

(1990b), "The International Debt Crisis and Bank Loan-Loss-Reserve Decisions: The Signaling Content of Partially Anticipated Events," Journal of Money, Credit, and Banking 22 (August): 370-87.

Robertson, Ross M. (1995), The Comptroller and Bank Supervision: A Historical Appraisal, (Washington, D.C.: Office of the Comptroller of the Currency).

Spillenkothen, Richard (1997a), "Risk-Focused Framework for Supervision of Large Complex Institutions," Supervision and Regulation Letter 97-24, Federal Reserve Board of Governors, (October).

(1997b), "Risk-Focused Framework for the Supervision of Community Banks," Supervision and Regulation Letter 97-25, Federal Reserve Board of Governors, (October).

(2001), "Final Interagency Policy Statement on Allowance for Loan and Lease Losses (ALLL) Methodologies and Documentation for Banks and Savings Institutions," Supervision and Regulation Letter 01-17, Federal Reserve Board of Governors, (July).

Townsend, Robert M. (1979), "Optimal Contracts and Competitive Markets with Costly State Verification," Journal of Economic Theory 21 (October): 265-93. 
Figure 1: Provision Expense ${ }^{a}$

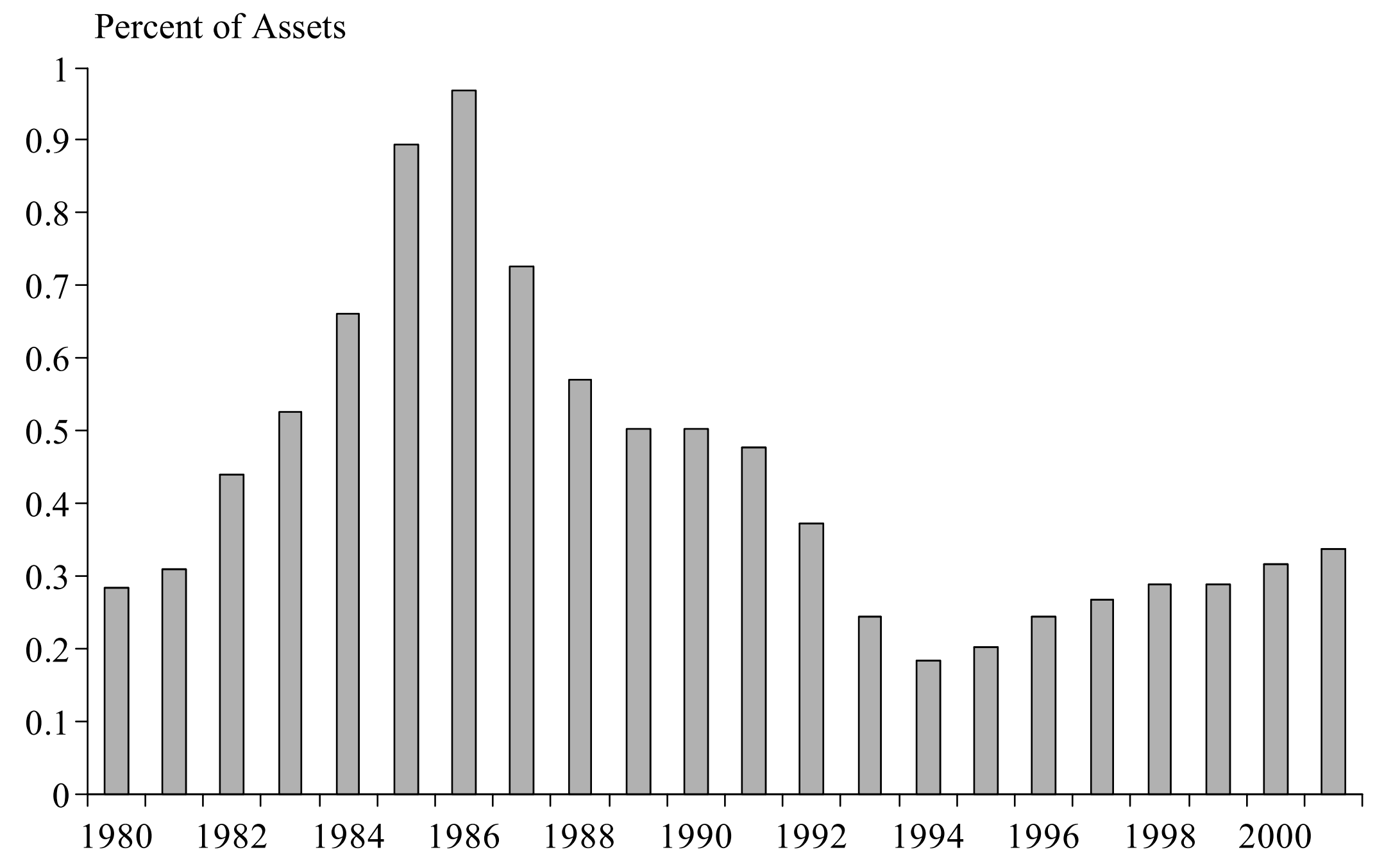

${ }^{\mathrm{a}}$ The figures shown are the mean values for all commercial banks. 
Figure 2: Distribution of RETURN ON ASSETS (Percent) for Banks with $E X A M=1$ and $R E V I S I O N=1$, Before and After Revisions, and for All Observations ${ }^{\mathrm{a}}$

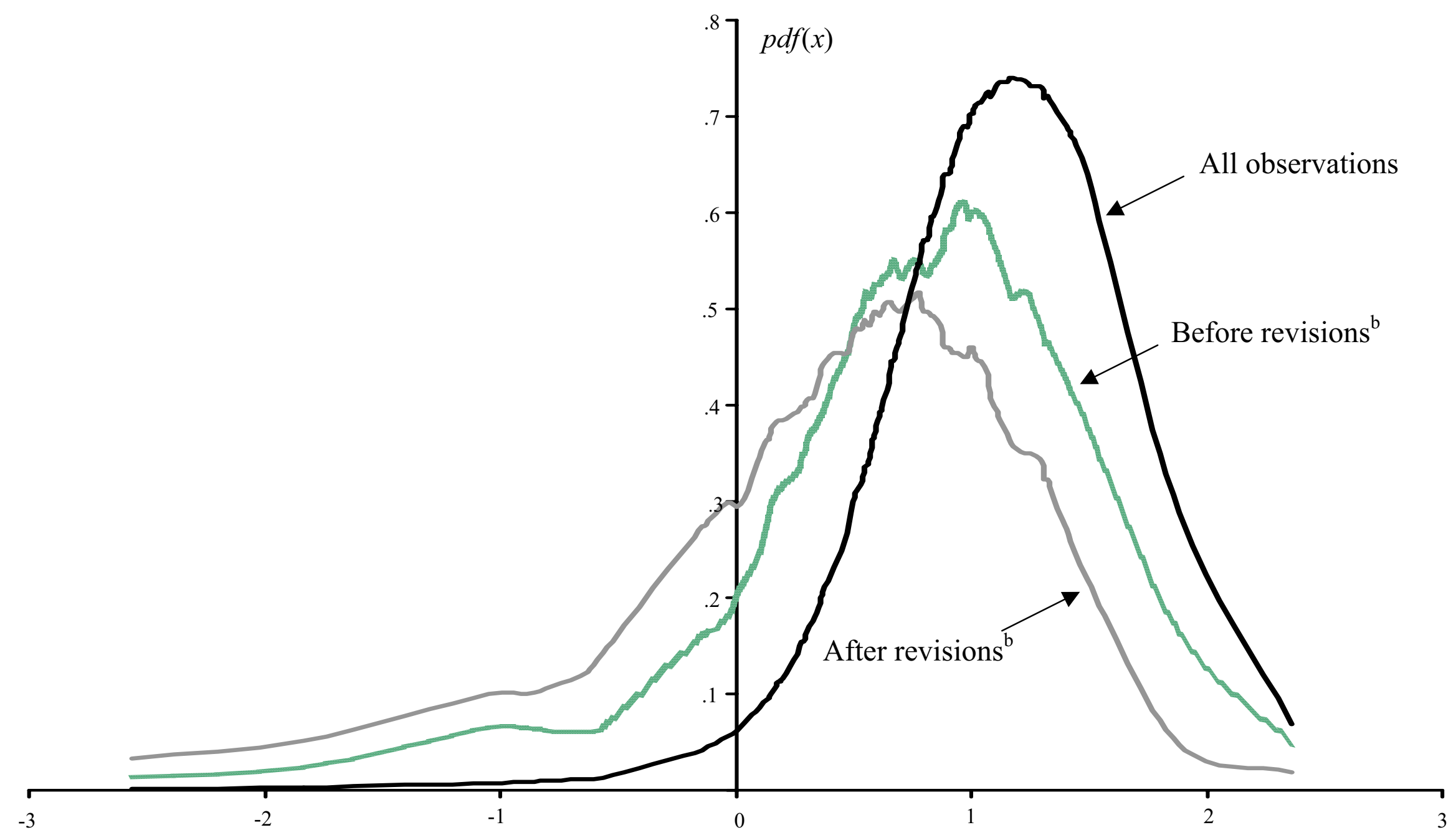

${ }^{\text {a }}$ The figures shown are based on a kernel density estimator, $p d f\left(x_{0}\right)=\frac{1}{N} \sum_{i=1}^{N} K\left(x_{i}-x_{0}\right)$, where $K(x)=1$ if $|x|<.5$, and zero otherwise, $N$ is the number of observations, and $x_{i}$ is $100 \cdot$ RETURN ON ASSETS.

${ }^{\mathrm{b}}$ Based on observations for which $E X A M=1$ and $R E V I S I O N=1$. 
Table 1: Incidence (Percent) of Revisions ${ }^{\mathrm{a}}$ to Numerators of Financial Ratios ${ }^{\mathrm{b}}$, by Quarter of Exam

Quarter of exam ${ }^{c}$

\begin{tabular}{|c|c|c|c|c|c|c|c|}
\hline & & First & Second & Third & Fourth & No exam & p-value \\
\hline \multirow[t]{3}{*}{ CAPITAL } & Positive & 2.34 & 3.16 & 2.29 & 2.50 & 2.05 & \\
\hline & Negative & 6.25 & 5.15 & 3.68 & 3.22 & 2.79 & .001 \\
\hline & $p$-value & .001 & .001 & .001 & .045 & .003 & \\
\hline \multirow[t]{3}{*}{ RESERVES } & Positive & 2.52 & 1.28 & 1.06 & .63 & .63 & \\
\hline & Negative & .76 & .50 & .37 & .37 & .23 & .001 \\
\hline & $p$-value & .001 & .001 & .001 & .088 & .001 & \\
\hline \multirow[t]{3}{*}{ PAST-DUE 90} & Positive & .35 & .21 & .09 & .03 & .04 & \\
\hline & Negative & .63 & .38 & .35 & .28 & .21 & .001 \\
\hline & p-value & .027 & .092 & .006 & .006 & .004 & \\
\hline \multirow[t]{3}{*}{ NONACCRUAL } & Positive & .74 & .29 & .18 & .20 & .08 & \\
\hline & Negative & .55 & .40 & .33 & .23 & .19 & .001 \\
\hline & $p$-value & .141 & .243 & .105 & .500 & .058 & \\
\hline \multirow[t]{3}{*}{ OTHER REAL ESTATE } & Positive & .29 & .29 & .11 & .14 & .17 & \\
\hline & Negative & .42 & .44 & .40 & .26 & .15 & .016 \\
\hline & $p$-value & .168 & .155 & .005 & .212 & .500 & \\
\hline \multirow[t]{3}{*}{ CHARGE-OFFS } & Positive & 1.55 & .75 & .57 & .63 & .39 & \\
\hline & Negative & .31 & .23 & .31 & .09 & .10 & .001 \\
\hline & $p$-value & .001 & .001 & .040 & .001 & .001 & \\
\hline \multirow[t]{3}{*}{ PROVISIONS } & Positive & 2.69 & 1.36 & 1.08 & .68 & .72 & \\
\hline & Negative & .31 & .25 & .26 & .06 & .17 & .001 \\
\hline & p-value & .001 & .001 & .001 & .001 & .001 & \\
\hline \multirow{3}{*}{ INC NOT COLLECTED } & Positive & .28 & .27 & .07 & .14 & .04 & \\
\hline & Negative & .85 & .54 & .46 & .23 & .32 & .001 \\
\hline & $p$-value & .001 & .027 & .001 & .291 & .001 & \\
\hline \multirow[t]{3}{*}{ RETURN ON ASSETS } & Positive & 1.95 & 2.51 & 2.20 & 2.33 & 1.74 & \\
\hline & Negative & 5.95 & 4.94 & 3.48 & 3.07 & 2.68 & .001 \\
\hline & p-value & .001 & .001 & .001 & .035 & .001 & \\
\hline \multirow[t]{3}{*}{ SECURITIES } & Positive & .50 & .40 & .26 & .26 & .15 & \\
\hline & Negative & .68 & .54 & .18 & .03 & .18 & .001 \\
\hline & $p$-value & .130 & .186 & .252 & .011 & .419 & \\
\hline \multirow[t]{3}{*}{$\mathrm{CASH}$} & Positive & .70 & .69 & .46 & .31 & .23 & \\
\hline & Negative & .57 & .77 & .42 & .43 & .29 & .001 \\
\hline & p-value & .235 & .360 & .437 & .279 & .314 & \\
\hline \multirow[t]{3}{*}{$L A R G E C D s$} & Positive & .13 & .17 & .04 & .06 & .11 & \\
\hline & Negative & .15 & .10 & .07 & .00 & .06 & .174 \\
\hline & $p$-value & .500 & .291 & .500 & .250 & .194 & \\
\hline \multicolumn{2}{|l|}{ Observations } & 5,426 & 4,780 & 4,542 & 3,514 & 7,252 & \\
\hline
\end{tabular}




\section{Notes to Table 1}

${ }^{a}$ Revisions are measured as the difference between the call report data as obtained in May 2000, and the original values of these data obtained when the data were first published as "final," about 65 days after the report date. Listed are the percentages of observations in each category for which the data were revised upward and downward, respectively.

${ }^{\mathrm{b}}$ The figures are for revisions to the numerators of the financial ratios, irrespective of whether the denominator (assets) was revised. CAPITAL, equity capital; RESERVES, loan loss reserves; PAST-DUE 90, loans past-due 90 days or more and still accruing; NONACCRUAL, nonaccrual loans; OTHER REAL ESTATE, other real estate owned; CHARGE-OFFS, loan chargeoffs less recoveries; PROVISIONS, provision for loan losses; INC NOT COLLECTED, income earned but not collected; RETURN ON ASSETS, net income; SECURITIES, investment securities; CASH, cash plus net fed funds sold; $L A R G E C D$, certificates of deposit of $\$ 100,000$ or more. CAPITAL, RESERVES, PAST-DUE 90, NONACCRUAL, OTHER REAL ESTATE, INC NOT COLLECTED, SECURITIES, CASH, and LARGE CDs are end-of-period values, scaled by end-of-period assets. CHARGE-OFFS, PROVISIONS, and RETURN ON ASSETS are annual values, divided by average assets for the year. The call report and exam data are from the Federal Reserve Board.

${ }^{c}$ The date of the first exam occurring in the year immediately following a year-end call report. The year-end call reports are from 1996-98.

d Significance levels (italics) are based on the Pearson chi-square test statistic for the null hypothesis of no association between the incidence of revisions (positive, negative, or none) and the incidence of exams (first, second, third, and fourth quarter, or none). The alternative hypothesis is general association.

e Significance levels (italics) are for the sign test based on the binomial distribution, under the assumption that upward and downward revisions are equally likely. Let $x$ correspond to the number of either upward or downward revisions, whichever is lower, and let $y$ be the total number of revisions. The significance level shown is the probability of observing $x$ or a lower value, given $y$. 
Table 2: Incidence (Percent) of Revisions to Financial Ratios, by Quarter of Exam ${ }^{\mathrm{a}}$

\begin{tabular}{|c|c|c|c|c|c|c|c|}
\hline & \multicolumn{4}{|c|}{ Quarter of exam } & \multirow[b]{2}{*}{ No exam } & \multirow[b]{2}{*}{$p$-value } \\
\hline & & First & Second & Third & Fourth & & \\
\hline \multirow[t]{3}{*}{ CAPITAL } & Positive & 2.91 & 3.62 & 2.44 & 2.76 & 2.29 & \\
\hline & Negative & 6.65 & 5.59 & 4.10 & 3.27 & 2.87 & .001 \\
\hline & $p$-value & .001 & .001 & .001 & .121 & .017 & \\
\hline \multirow{3}{*}{ RESERVES } & Positive & 5.05 & 3.97 & 2.62 & 2.28 & 2.04 & \\
\hline & Negative & 2.86 & 3.08 & 2.40 & 2.22 & 1.97 & .001 \\
\hline & $p$-value & .001 & .011 & .276 & .468 & .407 & \\
\hline \multirow[t]{3}{*}{ PAST-DUE 90} & Positive & 3.34 & 2.85 & 1.63 & 1.48 & 1.45 & \\
\hline & Negative & 2.93 & 2.95 & 2.36 & 2.11 & 1.85 & .001 \\
\hline & $p$-value & .127 & .405 & .009 & .030 & .035 & \\
\hline \multirow{3}{*}{ NONACCRUAL } & Positive & 3.72 & 2.95 & 1.74 & 1.96 & 1.42 & \\
\hline & Negative & 2.91 & 3.20 & 2.49 & 2.02 & 1.92 & .001 \\
\hline & $p$-value & .012 & .261 & .009 & .466 & .012 & \\
\hline \multirow[t]{3}{*}{ OTHER REAL ESTATE } & Positive & 2.19 & 2.03 & 1.12 & 1.14 & 1.10 & \\
\hline & Negative & 2.17 & 2.22 & 1.87 & 1.39 & 1.24 & .001 \\
\hline & $p$-value & .500 & .287 & .002 & .198 & .245 & \\
\hline \multirow[t]{3}{*}{ CHARGE-OFFS } & Positive & 4.35 & 3.39 & 2.40 & 2.19 & 1.97 & \\
\hline & Negative & 3.00 & 3.31 & 2.51 & 2.05 & 1.97 & .001 \\
\hline & $p$-value & .001 & .433 & .394 & .372 & .524 & \\
\hline \multirow[t]{3}{*}{ PROVISIONS } & Positive & 5.14 & 3.72 & 2.60 & 2.16 & 1.96 & \\
\hline & Negative & 2.14 & 2.55 & 2.07 & 1.76 & 1.70 & .001 \\
\hline & $p$-value & .001 & .001 & .057 & .134 & .134 & \\
\hline \multirow[t]{3}{*}{ INC NOT COLLECTED } & Positive & 3.72 & 3.16 & 1.81 & 1.94 & 1.57 & \\
\hline & Negative & 3.65 & 3.58 & 3.06 & 2.36 & 2.34 & .001 \\
\hline & $p$-value & .440 & .145 & .001 & .127 & .001 & \\
\hline \multirow[t]{3}{*}{ RETURN ON ASSETS } & Positive & 2.84 & 3.12 & 2.47 & 2.73 & 2.11 & \\
\hline & Negative & 6.71 & 5.86 & 4.14 & 3.27 & 2.94 & .001 \\
\hline & $p$-value & .001 & .001 & .001 & .108 & .001 & \\
\hline \multirow[t]{3}{*}{ SECURITIES } & Positive & 4.29 & 3.45 & 2.20 & 2.16 & 1.86 & \\
\hline & Negative & 3.19 & 3.35 & 2.69 & 2.16 & 2.11 & .001 \\
\hline & $p$-value & .002 & .412 & .079 & .532 & .158 & \\
\hline \multirow[t]{3}{*}{$\mathrm{CASH}$} & Positive & 4.31 & 3.45 & 2.55 & 2.08 & 1.89 & \\
\hline & Negative & 3.24 & 3.43 & 2.40 & 2.31 & 2.08 & .001 \\
\hline & $p$-value & .002 & .500 & .345 & .287 & .222 & \\
\hline \multirow[t]{3}{*}{$L A R G E C D s$} & Positive & 4.26 & 3.56 & 2.14 & 2.08 & 1.94 & \\
\hline & Negative & 3.08 & 3.33 & 2.71 & 2.25 & 2.08 & .001 \\
\hline & $p$-value & .001 & .291 & .046 & .343 & .299 & \\
\hline \multicolumn{2}{|l|}{ Observations } & 5,426 & 4,780 & 4,542 & 3,514 & 7,252 & \\
\hline
\end{tabular}

${ }^{\mathrm{a}}$ The figures are for revisions to the financial ratios resulting from changes to the numerator, denominator (assets), or both. 
Table 3: Incidence (Percent) of Revisions to Numerators of Financial Ratios, by Quarter of Supervisory Downgrade

Quarter of downgrade ${ }^{\mathrm{a}}$

\begin{tabular}{|c|c|c|c|c|c|c|c|}
\hline & & First & Second & Third & Fourth & No downgrade & $p$-value \\
\hline \multirow[t]{3}{*}{ CAPITAL } & Positive & 3.31 & 4.14 & 2.78 & 3.72 & 2.48 & \\
\hline & Negative & 18.22 & 9.66 & 6.02 & 2.87 & 4.22 & .001 \\
\hline & $p$-value & .001 & .001 & .017 & .339 & .001 & \\
\hline \multirow[t]{3}{*}{ RESERVES } & Positive & 12.42 & 3.22 & 2.08 & .86 & 1.10 & \\
\hline & Negative & 1.45 & 1.61 & 1.39 & .29 & .45 & .001 \\
\hline & $p$-value & .001 & .095 & .304 & .313 & .001 & \\
\hline \multirow[t]{3}{*}{ PAST-DUE 90} & Positive & .83 & .46 & .00 & .00 & .17 & \\
\hline & Negative & 3.11 & 1.84 & .46 & .29 & .31 & .001 \\
\hline & $p$-value & .010 & .055 & .250 & .500 & .005 & \\
\hline \multirow{3}{*}{ NONACCRUAL } & Positive & 3.52 & .69 & .23 & .29 & .28 & \\
\hline & Negative & 2.28 & 1.38 & 1.62 & .29 & .28 & .001 \\
\hline & $p$-value & .172 & .254 & .035 & .750 & .541 & \\
\hline \multirow[t]{3}{*}{ OTHER REAL ESTATE } & Positive & .62 & .92 & .23 & .29 & .19 & \\
\hline & Negative & .21 & .46 & 1.85 & .29 & .36 & .001 \\
\hline & $p$-value & .313 & .344 & .020 & .750 & .002 & \\
\hline \multirow{3}{*}{ CHARGE-OFFS } & Positive & 5.38 & 2.53 & 1.62 & .57 & .74 & \\
\hline & Negative & .21 & .00 & .93 & .00 & .24 & .001 \\
\hline & p-value & .001 & .001 & .274 & .250 & .001 & \\
\hline \multirow[t]{3}{*}{ PROVISIONS } & Positive & 13.46 & 4.37 & 2.55 & .86 & 1.12 & \\
\hline & Negative & .41 & .46 & .46 & .57 & .21 & .001 \\
\hline & $p$-value & .001 & .001 & .011 & .500 & .001 & \\
\hline \multirow{3}{*}{ INC NOT COLLECTED } & Positive & .83 & .92 & .23 & .00 & .16 & \\
\hline & Negative & 4.14 & 1.84 & .69 & .00 & .42 & .001 \\
\hline & $p$-value & .001 & .194 & .313 & Q & .001 & \\
\hline \multirow[t]{3}{*}{ RETURN ON ASSETS } & Positive & 2.28 & 3.45 & 2.08 & 3.44 & 2.18 & \\
\hline & Negative & 17.18 & 8.97 & 6.02 & 2.58 & 4.03 & .001 \\
\hline & p-value & .001 & .001 & .003 & .332 & .001 & \\
\hline \multirow[t]{3}{*}{ SECURITIES } & Positive & 1.45 & .46 & .23 & .57 & .33 & \\
\hline & Negative & 1.45 & .92 & .46 & .00 & .36 & .001 \\
\hline & p-value & .605 & .344 & .500 & .250 & .389 & \\
\hline \multirow[t]{3}{*}{$\mathrm{CASH}$} & Positive & 1.24 & 1.15 & .93 & .57 & .52 & \\
\hline & Negative & 1.45 & 2.07 & .93 & .29 & .49 & .001 \\
\hline & p-value & .500 & .212 & .637 & .500 & .379 & \\
\hline \multirow[t]{3}{*}{ LARGE CDs } & Positive & .21 & .00 & .23 & .00 & .10 & \\
\hline & Negative & .00 & .46 & .23 & .00 & .08 & .215 \\
\hline & $p$-value & .500 & .250 & .750 & Q & .292 & \\
\hline Observations & & 483 & 435 & 432 & 349 & 16,563 & \\
\hline
\end{tabular}




\section{Notes to Table 3}

${ }^{a}$ Composite safety and soundness ratings have five levels: 1 - basically sound in every respect; 2 - fundamentally sound but with modest weaknesses; 3 - financial, operational, or compliance weaknesses that cause supervisory concern; 4-serious financial weaknesses that could impair future viability; and 5-critical financial weaknesses that render the probability of nearterm failure extremely high. A downgrade occurs when a bank receives a worse rating on its current exam than on its previous one. The quarters correspond to the date of the first exam occurring in the year immediately following a year-end call report. The year-end call reports are from 1996-98. The fifth column contains figures for banks that were examined during the year but not downgraded. No significance level is shown for cases where no revision occurred. 
Table 4: Incidence (Percent) of Revisions to Financial Ratios, by Quarter of Supervisory Downgrade

Quarter of downgrade

\begin{tabular}{|c|c|c|c|c|c|c|c|}
\hline & & First & Second & Third & Fourth & No downgrade & $p$-value \\
\hline \multirow[t]{3}{*}{ CAPITAL } & Positive & 3.93 & 4.83 & 3.24 & 4.01 & 2.84 & \\
\hline & Negative & 18.84 & 10.11 & 6.25 & 2.87 & 4.57 & .001 \\
\hline & p-value & .001 & .003 & .030 & .271 & .001 & \\
\hline \multirow[t]{3}{*}{ RESERVES } & Positive & 16.56 & 7.82 & 3.94 & 2.87 & 3.15 & \\
\hline & Negative & 4.76 & 5.29 & 3.47 & 3.44 & 2.51 & .001 \\
\hline & p-value & .001 & .092 & .430 & .416 & .001 & \\
\hline \multirow[t]{3}{*}{ PAST-DUE 90} & Positive & 6.83 & 5.52 & 3.01 & 1.72 & 2.22 & \\
\hline & Negative & 8.90 & 7.36 & 2.55 & 3.15 & 2.32 & .001 \\
\hline & $p$-value & .151 & .175 & .419 & .166 & .280 & \\
\hline \multirow[t]{3}{*}{ NONACCRUAL } & Positive & 9.11 & 5.52 & 2.55 & 2.29 & 2.43 & \\
\hline & Negative & 8.28 & 6.44 & 3.70 & 3.44 & 2.41 & .001 \\
\hline & $p$-value & .372 & .339 & .221 & .252 & .444 & \\
\hline \multirow[t]{3}{*}{ OTHER REAL ESTATE } & Positive & 4.97 & 5.06 & 1.16 & 1.72 & 1.51 & \\
\hline & Negative & 4.76 & 3.45 & 3.70 & 2.58 & 1.78 & .001 \\
\hline & p-value & .500 & .162 & .013 & .304 & .030 & \\
\hline \multirow[t]{3}{*}{ CHARGE-OFFS } & Positive & 10.97 & 7.36 & 3.24 & 2.58 & 2.87 & \\
\hline & Negative & 7.45 & 5.29 & 3.47 & 3.15 & 2.55 & .001 \\
\hline & $p$-value & .045 & .140 & .500 & .412 & .038 & \\
\hline \multirow[t]{3}{*}{ PROVISIONS } & Positive & 18.22 & 8.74 & 4.17 & 2.29 & 3.01 & \\
\hline & Negative & 2.69 & 3.45 & 2.08 & 3.72 & 2.08 & .001 \\
\hline & $p$-value & .001 & .001 & .061 & .192 & .001 & \\
\hline \multirow[t]{3}{*}{ INC NOT COLLECTED } & Positive & 7.45 & 5.75 & 3.94 & 2.01 & 2.52 & \\
\hline & Negative & 10.97 & 6.90 & 3.01 & 4.01 & 2.90 & .001 \\
\hline & $p$-value & .045 & .295 & .292 & .095 & .019 & \\
\hline \multirow[t]{3}{*}{ RETURN ON ASSETS } & Positive & 3.93 & 4.60 & 2.55 & 3.72 & 2.70 & \\
\hline & Negative & 18.63 & 9.89 & 6.71 & 3.15 & 4.67 & .001 \\
\hline & $p$-value & .001 & .003 & .003 & .419 & .001 & \\
\hline \multirow[t]{3}{*}{ SECURITIES } & Positive & 11.39 & 6.44 & 4.17 & 2.01 & 2.81 & \\
\hline & Negative & 7.04 & 6.21 & 3.01 & 3.72 & 2.68 & .001 \\
\hline & $p$-value & .017 & .500 & .237 & .132 & .243 & \\
\hline \multirow[t]{3}{*}{ CASH } & Positive & 10.77 & 5.52 & 4.86 & 2.29 & 2.92 & \\
\hline & Negative & 8.07 & 7.36 & 2.78 & 3.72 & 2.62 & .001 \\
\hline & $p$-value & .104 & .175 & .081 & .192 & .056 & \\
\hline \multirow[t]{3}{*}{$L A R G E C D s$} & Positive & 10.77 & 6.44 & 3.94 & 2.01 & 2.82 & \\
\hline & Negative & 7.25 & 5.98 & 3.01 & 4.01 & 2.66 & .001 \\
\hline & $p$-value & .043 & .446 & .292 & .095 & .194 & \\
\hline \multicolumn{2}{|l|}{ Observations } & 483 & 435 & 432 & 349 & 16,563 & \\
\hline
\end{tabular}


Table 5: Variable Means, by REVISION ${ }^{\text {a }}$

\begin{tabular}{|c|c|c|c|c|c|c|}
\hline & \multicolumn{3}{|c|}{ Original data } & \multicolumn{3}{|c|}{ Revised data } \\
\hline & REVISION $=0$ & REVISION $=1$ & $p$-value ${ }^{\mathrm{b}}$ & REVISION $=0$ & REVISION $=1$ & $p$-value ${ }^{\mathrm{b}}$ \\
\hline$S I Z E^{\mathrm{c}}$ & 11.32 & 11.16 & .151 & 11.32 & 11.16 & .144 \\
\hline CAMELS $-1^{\mathrm{d}}$ & 1.56 & 2.23 & .001 & 1.56 & 2.23 & .001 \\
\hline CAPITAL $^{\mathrm{e}}$ & 10.17 & 9.48 & .001 & 10.17 & 9.02 & .001 \\
\hline RESERVES ${ }^{\mathrm{e}}$ & .87 & .95 & .316 & .87 & 1.25 & .001 \\
\hline PAST-DUE $90^{\mathrm{e}}$ & .21 & .52 & .001 & .21 & .46 & .001 \\
\hline NONACCRUAL ${ }^{\mathrm{e}}$ & .37 & .90 & .001 & .37 & .91 & .001 \\
\hline OTHER REAL ESTATE ${ }^{\mathrm{e}}$ & .13 & .32 & .001 & .13 & .36 & .001 \\
\hline CHARGE-OFFS ${ }^{\mathrm{e}}$ & .16 & .51 & .001 & .16 & .80 & .001 \\
\hline PROVISIONS ${ }^{\mathrm{e}}$ & .21 & .61 & .001 & .21 & 1.20 & .001 \\
\hline INC NOT COLLECTED ${ }^{\mathrm{e}}$ & .67 & .72 & .018 & .67 & .72 & .047 \\
\hline RETURN ON ASSETS ${ }^{\mathrm{e}}$ & 1.21 & .67 & .001 & 1.20 & .20 & .001 \\
\hline SECURITIES $\mathrm{e}^{\mathrm{e}}$ & 27.99 & 21.51 & .001 & 27.99 & 21.53 & .001 \\
\hline$C A S H^{\mathrm{e}}$ & 8.85 & 10.61 & .001 & 8.85 & 10.62 & .001 \\
\hline$L A R G E C D s^{\mathrm{e}}$ & 10.05 & 12.17 & .001 & 10.06 & 12.17 & .001 \\
\hline Observations & 25,178 & 336 & & 25,178 & 336 & \\
\hline
\end{tabular}

${ }^{a}$ REVISION is a binary variable for whether a bank revised its provision expense (numerator of PROVISIONS) upward.

${ }^{\mathrm{b}}$ For $C A M E L S$-1, significance levels are based on the Pearson chi-square test statistic for the null hypothesis of no association with REVISION. Significance levels for the remaining variables are based on the Wilcoxon test statistic for a shift in location parameter.

${ }^{\mathrm{c}} S I Z E$ is $\log$ of total assets.

${ }^{\mathrm{d}}$ CAMELS-1 is the previous safety and soundness rating.

${ }^{\mathrm{e}}$ The financial ratios are multiplied by 100 . 
Table 6: Regression Results for REVISION ${ }^{\text {a }}$

Ordinary least squares

Probit

\begin{tabular}{|c|c|c|c|c|}
\hline & Original data & Revised data & Original data & Revised data \\
\hline Constant & $\begin{array}{c}.0105 \\
(.0098)\end{array}$ & $\begin{array}{c}.0142 \\
(.0096)\end{array}$ & $\begin{array}{l}2.324^{*} \\
(.3245)\end{array}$ & $\begin{array}{l}2.187^{*} \\
(.3348)\end{array}$ \\
\hline$E X A M 1^{\mathrm{b}}$ & $\begin{array}{l}.0174^{*} \\
(.0020)\end{array}$ & $\begin{array}{l}.0163 * \\
(.0020)\end{array}$ & $\begin{array}{l}.4935^{*} \\
(.0662)\end{array}$ & $\begin{array}{l}.4705^{*} \\
(.0674)\end{array}$ \\
\hline$E X A M 2^{\mathrm{b}}$ & $\begin{array}{l}.0044 \dagger \\
(.0021)\end{array}$ & $\begin{array}{c}.0038 \\
(.0021)\end{array}$ & $\begin{array}{l}.1851 \dagger \\
(.0756)\end{array}$ & $\begin{array}{l}.1622 \dagger \\
(.0776)\end{array}$ \\
\hline$E X A M 3^{\mathrm{b}}$ & $\begin{array}{c}.0022 \\
(.0021)\end{array}$ & $\begin{array}{c}.0022 \\
(.0021)\end{array}$ & $\begin{array}{c}.1190 \\
(.0798)\end{array}$ & $\begin{array}{c}.1259 \\
(.0809)\end{array}$ \\
\hline$E X A M 4^{\mathrm{b}}$ & $\begin{array}{l}-.0013 \\
(.0023)\end{array}$ & $\begin{array}{l}-.0011 \\
(.0023)\end{array}$ & $\begin{array}{l}-.0639 \\
(.0969)\end{array}$ & $\begin{array}{l}-.0641 \\
(.0991)\end{array}$ \\
\hline SIZE & $\begin{array}{l}-.0013 \\
(.0007)\end{array}$ & $\begin{array}{l}-.0019^{*} \\
(.0007)\end{array}$ & $\begin{array}{c}-.0284 \\
(.0228)\end{array}$ & $\begin{array}{l}-.0324 \\
(.0236)\end{array}$ \\
\hline CAMELS-1 & $\begin{array}{l}.0131^{*} \\
(.0014)\end{array}$ & $\begin{array}{l}.0067^{*} \\
(.0014)\end{array}$ & $\begin{array}{l}.3682 * \\
(.0418)\end{array}$ & $\begin{array}{l}.2204^{*} \\
(.0429)\end{array}$ \\
\hline CAPITAL & $\begin{array}{c}.0219 \\
(.0181)\end{array}$ & $\begin{array}{c}.0078 \\
(.0177)\end{array}$ & $\begin{array}{c}.5534 \\
(.4806)\end{array}$ & $\begin{array}{c}.2031 \\
(.5624)\end{array}$ \\
\hline RESERVES & $\begin{array}{c}-1.291^{*} \\
(.1808)\end{array}$ & $\begin{array}{l}-.3189 \\
(.1764)\end{array}$ & $\begin{array}{c}-41.88^{*} \\
(6.534)\end{array}$ & $\begin{array}{c}-25.21^{*} \\
(6.141)\end{array}$ \\
\hline PAST-DUE 90 & $\begin{array}{l}1.184 * \\
(.1693)\end{array}$ & $\begin{array}{c}.0565 \\
(.1699)\end{array}$ & $\begin{array}{l}10.77 * \\
(3.287)\end{array}$ & $\begin{array}{c}.8720 \\
(3.824)\end{array}$ \\
\hline NONACCRUAL & $\begin{array}{l}.9799^{*} \\
(.1329)\end{array}$ & $\begin{array}{l}.4635^{*} \\
(.1291)\end{array}$ & $\begin{array}{l}13.06^{*} \\
(2.865)\end{array}$ & $\begin{array}{l}8.375^{*} \\
(2.931)\end{array}$ \\
\hline OTHER REAL ESTATE & $\begin{array}{l}.4822 \dagger \\
(.2061)\end{array}$ & $\begin{array}{l}1.195^{*} \\
(.1954)\end{array}$ & $\begin{array}{c}.6274 \\
(4.308)\end{array}$ & $\begin{array}{l}8.768 \dagger \\
(3.872)\end{array}$ \\
\hline CHARGE-OFFS & $\begin{array}{l}.7068 \dagger \\
(.3356)\end{array}$ & $\begin{array}{l}-3.136^{*} \\
(.3262)\end{array}$ & $\begin{array}{c}4.117 \\
(7.671)\end{array}$ & $\begin{array}{c}-36.76^{*} \\
(8.601)\end{array}$ \\
\hline PROVISIONS & $\begin{array}{l}1.120^{*} \\
(.3039)\end{array}$ & $\begin{array}{l}7.345^{*} \\
(.2939)\end{array}$ & $\begin{array}{c}17.30 \dagger \\
(7.014)\end{array}$ & $\begin{array}{l}62.18^{*} \\
(8.120)\end{array}$ \\
\hline INC NOT COLLECTED & $\begin{array}{c}-.4130 \dagger \\
(.1742)\end{array}$ & $\begin{array}{l}-.4883^{*} \\
(.1714)\end{array}$ & $\begin{array}{c}-6.833 \\
(5.390)\end{array}$ & $\begin{array}{c}-6.386 \\
(5.507)\end{array}$ \\
\hline RETURN ON ASSETS & $\begin{array}{l}-.2185^{*} \\
(.0729)\end{array}$ & $\begin{array}{l}-.4660^{*} \\
(.0702)\end{array}$ & $\begin{array}{l}-3.681 \\
(2.522)\end{array}$ & $\begin{array}{c}-10.25^{*} \\
(2.674)\end{array}$ \\
\hline SECURITIES & $\begin{array}{l}-.0266^{*} \\
(.0061)\end{array}$ & $\begin{array}{l}-.0030 \\
(.0059)\end{array}$ & $\begin{array}{c}-1.138^{*} \\
(.2114)\end{array}$ & $\begin{array}{c}-.8145^{*} \\
(.2126)\end{array}$ \\
\hline CASH & $\begin{array}{l}-.0005 \\
(.0092)\end{array}$ & $\begin{array}{l}.0181 \dagger \\
(.0091)\end{array}$ & $\begin{array}{c}-.3183 \\
(.2864)\end{array}$ & $\begin{array}{l}-.0690 \\
(.2936)\end{array}$ \\
\hline$L A R G E C D s$ & $\begin{array}{l}.0281 \dagger \\
(.0113)\end{array}$ & $\begin{array}{c}.0153 \\
(.0110)\end{array}$ & $\begin{array}{l}.8937^{*} \\
(.3216)\end{array}$ & $\begin{array}{l}.8831^{*} \\
(.3327)\end{array}$ \\
\hline
\end{tabular}

${ }^{\mathrm{a}}$ Standard errors are in parentheses. * Significant at the 1-percent level. $\dagger$ Significant at the 5-percent level.

${ }^{\mathrm{b}}$ EXAM1 is a binary indicator for whether a bank's first exam in the year immediately following a year-end call report occurred in the first quarter, EXAM2 is a binary indicator for banks examined in the second quarter, and so on for EXAM3 and EXAM4. 
Table 7: Variable Means, by EXAM

\begin{tabular}{|c|c|c|c|c|c|c|}
\hline & \multicolumn{3}{|c|}{ Original data } & \multicolumn{3}{|c|}{ Revised data } \\
\hline & $E X A M=0$ & $E X A M=1$ & $p$-value ${ }^{\mathrm{b}}$ & $E X A M=0$ & $E X A M=1$ & $p$-value ${ }^{\mathrm{b}}$ \\
\hline FREQUENCY ${ }^{\mathrm{c}}$ & 4.16 & 2.22 & .001 & 4.16 & 2.22 & .001 \\
\hline SIZE & 11.32 & 11.32 & .368 & 11.32 & 11.32 & .367 \\
\hline$C A M E L S-1$ & 1.55 & 1.61 & .001 & 1.55 & 1.61 & .001 \\
\hline CAPITAL $^{\mathrm{d}}$ & 10.19 & 10.11 & .892 & 10.19 & 10.10 & .925 \\
\hline RESERVES ${ }^{\mathrm{d}}$ & .86 & .88 & .001 & .86 & .89 & .001 \\
\hline PAST-DUE $90^{\mathrm{d}}$ & .21 & .23 & .046 & .21 & .23 & .043 \\
\hline NONACCRUAL ${ }^{\mathrm{d}}$ & .36 & .40 & .001 & .36 & .40 & .001 \\
\hline OTHER REAL ESTATE ${ }^{\mathrm{d}}$ & .14 & .14 & .454 & .14 & .14 & .414 \\
\hline CHARGE-OFFS ${ }^{\mathrm{d}}$ & .16 & .17 & .203 & .16 & .18 & .097 \\
\hline PROVISIONS ${ }^{\mathrm{d}}$ & .21 & .23 & .001 & .21 & .24 & .001 \\
\hline INC NOT COLLECTED ${ }^{\mathrm{d}}$ & .67 & .68 & .035 & .67 & .68 & .037 \\
\hline RETURN ON ASSETS ${ }^{\mathrm{d}}$ & 1.22 & 1.17 & .019 & 1.21 & 1.16 & .004 \\
\hline SECURITIES ${ }^{\mathrm{d}}$ & 27.95 & 27.84 & .761 & 27.96 & 27.83 & .748 \\
\hline$C A S H^{\mathrm{d}}$ & 8.94 & 8.76 & .109 & 8.94 & 8.76 & .108 \\
\hline$L A R G E C D s^{\mathrm{d}}$ & 10.03 & 10.16 & .484 & 10.03 & 10.16 & .479 \\
\hline Observations & 15,308 & 10,206 & & 15,308 & 10,206 & \\
\hline
\end{tabular}

a EXAM is a binary indicator for whether a bank's first exam in the year immediately following a year-end call report occurred in the first half.

${ }^{\mathrm{b}}$ For FREQUENCY and CAMELS-1, significance levels are based on the Pearson chi-square test statistic for the null hypothesis of no association with EXAM. Significance levels for the remaining variables are based on the Wilcoxon test statistic for a shift in location parameter.

${ }^{\mathrm{c}}$ FREQUENCY is the number of quarters remaining in the exam frequency guidelines.

${ }^{\mathrm{d}}$ The financial ratios are multiplied by 100 . 
Table 8: Two-Stage Least Squares Regression Results for REVISION

\begin{tabular}{|c|c|c|c|c|}
\hline & \multicolumn{2}{|c|}{ EXAM } & \multicolumn{2}{|c|}{ REVISION } \\
\hline & Original data & Revised data & Original data & Revised data \\
\hline Constant & $\begin{array}{l}1.522 * \\
(.0370)\end{array}$ & $\begin{array}{l}1.526^{*} \\
(.0370)\end{array}$ & $\begin{array}{c}.0085 \\
(.0099)\end{array}$ & $\begin{array}{c}.0124 \\
(.0097)\end{array}$ \\
\hline FREQUENCY & $\begin{array}{l}-.1657^{*} \\
(.0015)\end{array}$ & $\begin{array}{l}-.1657^{*} \\
(.0015)\end{array}$ & & \\
\hline$E X A M$ & & & $\begin{array}{l}.0164^{*} \\
(.0025)\end{array}$ & $\begin{array}{l}.0153^{*} \\
(.0025)\end{array}$ \\
\hline SIZE & $\begin{array}{l}-.0505^{*} \\
(.0024)\end{array}$ & $\begin{array}{l}-.0507^{*} \\
(.0024)\end{array}$ & $\begin{array}{l}-.0012 \\
(.0007)\end{array}$ & $\begin{array}{l}-.0019 * \\
(.0007)\end{array}$ \\
\hline CAMELS-1 & $\begin{array}{l}.0170^{*} \\
(.0050)\end{array}$ & $\begin{array}{l}.0150^{*} \\
(.0050)\end{array}$ & $\begin{array}{l}.0130^{*} \\
(.0014)\end{array}$ & $\begin{array}{l}.0066^{*} \\
(.0014)\end{array}$ \\
\hline CAPITAL & $\begin{array}{c}-.1184 \\
(.0650)\end{array}$ & $\begin{array}{c}-.1186 \\
(.0650)\end{array}$ & $\begin{array}{c}.0219 \\
(.0181)\end{array}$ & $\begin{array}{c}.0078 \\
(.0177)\end{array}$ \\
\hline RESERVES & $\begin{array}{c}.8675 \\
(.6496)\end{array}$ & $\begin{array}{c}.8083 \\
(.6468)\end{array}$ & $\begin{array}{c}-1.300^{*} \\
(.1810)\end{array}$ & $\begin{array}{l}-.3271 \\
(.1766)\end{array}$ \\
\hline PAST-DUE 90 & $\begin{array}{c}.2409 \\
(.6082)\end{array}$ & $\begin{array}{c}.2674 \\
(.6230)\end{array}$ & $\begin{array}{l}1.193 * \\
(.1694)\end{array}$ & $\begin{array}{c}.0624 \\
(.1700)\end{array}$ \\
\hline NONACCRUAL & $\begin{array}{c}.3420 \\
(.4777)\end{array}$ & $\begin{array}{c}.3244 \\
(.4736)\end{array}$ & $\begin{array}{l}.9692 * \\
(.1331)\end{array}$ & $\begin{array}{l}.4544^{*} \\
(.1293)\end{array}$ \\
\hline OTHER REAL ESTATE & $\begin{array}{c}-2.162^{*} \\
(.7404)\end{array}$ & $\begin{array}{c}-1.740 \dagger \\
(.7162)\end{array}$ & $\begin{array}{l}.4913 \dagger \\
(.2063)\end{array}$ & $\begin{array}{l}1.203 * \\
(.1955)\end{array}$ \\
\hline CHARGE-OFFS & $\begin{array}{c}-1.827 \\
(1.206)\end{array}$ & $\begin{array}{c}-2.393 \dagger \\
(1.196)\end{array}$ & $\begin{array}{l}.7202 \dagger \\
(.3359)\end{array}$ & $\begin{array}{c}-3.126^{*} \\
(.3266)\end{array}$ \\
\hline PROVISIONS & $\begin{array}{c}.9727 \\
(1.092)\end{array}$ & $\begin{array}{c}1.993 \\
(1.078)\end{array}$ & $\begin{array}{l}1.111^{*} \\
(.3042)\end{array}$ & $\begin{array}{l}7.341^{*} \\
(.2942)\end{array}$ \\
\hline INC NOT COLLECTED & $\begin{array}{c}.6035 \\
(.6257)\end{array}$ & $\begin{array}{c}.5959 \\
(.6284)\end{array}$ & $\begin{array}{l}-.4265 \dagger \\
(.1743)\end{array}$ & $\begin{array}{l}-.5010^{*} \\
(.1715)\end{array}$ \\
\hline RETURN ON ASSETS & $\begin{array}{c}-.1492 \\
(.2619)\end{array}$ & $\begin{array}{c}-.1826 \\
(.2574)\end{array}$ & $\begin{array}{l}-.2178^{*} \\
(.0730)\end{array}$ & $\begin{array}{l}-.4652 * \\
(.0703)\end{array}$ \\
\hline SECURITIES & $\begin{array}{c}.0178 \\
(.0218)\end{array}$ & $\begin{array}{c}.0190 \\
(.0217)\end{array}$ & $\begin{array}{l}-.0268^{*} \\
(.0061)\end{array}$ & $\begin{array}{c}-.0032 \\
(.0059)\end{array}$ \\
\hline $\mathrm{CASH}$ & $\begin{array}{l}-.2356^{*} \\
(.0332)\end{array}$ & $\begin{array}{l}-.2350^{*} \\
(.0332)\end{array}$ & $\begin{array}{c}-.0001 \\
(.0092)\end{array}$ & $\begin{array}{l}.0186 \dagger \\
(.0091)\end{array}$ \\
\hline LARGE CDs & $\begin{array}{c}.0416 \\
(.0404)\end{array}$ & $\begin{array}{c}.0393 \\
(.0404)\end{array}$ & $\begin{array}{l}.0278 \dagger \\
(.0113)\end{array}$ & $\begin{array}{c}.0150 \\
(.0110)\end{array}$ \\
\hline
\end{tabular}

* Significant at the 1-percent level. $\dagger$ Significant at the 5-percent level. 
Table 9: Means of Financial Ratios ${ }^{\mathrm{a}}$, EXAM $=1$ and $R E V I S I O N=1$

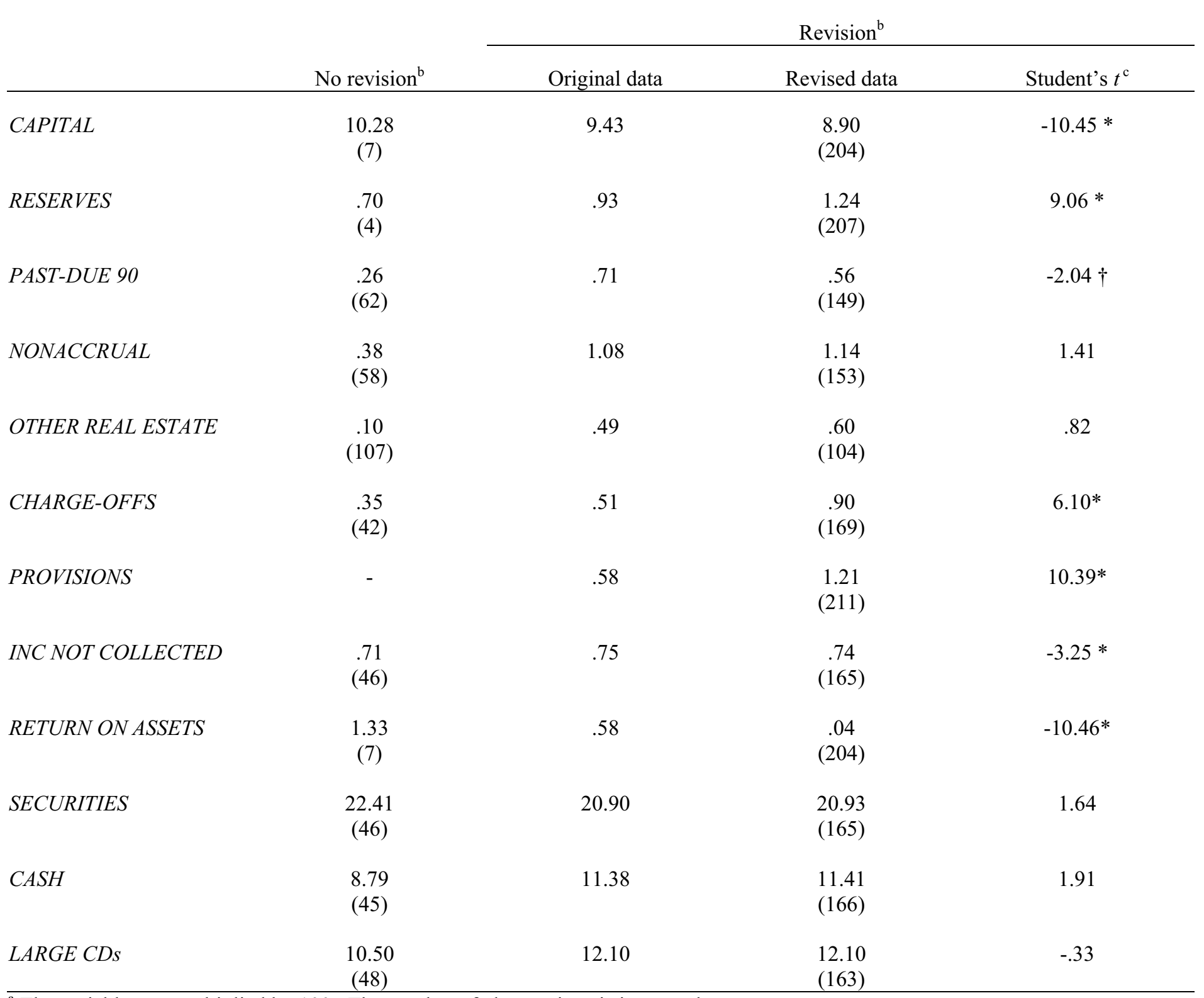

${ }^{\mathrm{a}}$ The variables are multiplied by 100 . The number of observations is in parentheses.

${ }^{\mathrm{b}}$ The observations are grouped according to whether a particular financial ratio was revised, in addition to the upward revision in provision expense.

${ }^{\mathrm{c}}$ The number in each row is the Student's $t$ value for the null hypothesis that the mean difference between the originally reported and subsequently revised financial ratio is zero. * Significant at the 1-percent level. $†$ Significant at the 5-percent level. 
Table 10: Two-Stage Least Squares Regression Results for REVISION

$(C A M E L S-1=1 \text { or } 2)^{\mathrm{a}}$

\begin{tabular}{|c|c|c|c|c|}
\hline & \multicolumn{2}{|c|}{$E X A M$} & \multicolumn{2}{|c|}{ REVISION } \\
\hline & Original data & Revised data & Original data & Revised data \\
\hline Constant & $\begin{array}{l}1.510^{*} \\
(.0377)\end{array}$ & $\begin{array}{l}1.511^{*} \\
(.0377)\end{array}$ & $\begin{array}{l}.0219 \dagger \\
(.0089)\end{array}$ & $\begin{array}{l}.0209 \dagger \\
(.0087)\end{array}$ \\
\hline FREQUENCY & $\begin{array}{c}-.1662^{*} \\
(.0015)\end{array}$ & $\begin{array}{l}-.1662 * \\
(.0015)\end{array}$ & & \\
\hline$E X A M$ & & & $\begin{array}{l}.0136^{*} \\
(.0023)\end{array}$ & $\begin{array}{l}.0128^{*} \\
(.0022)\end{array}$ \\
\hline SIZE & $\begin{array}{l}-.0510^{*} \\
(.0025)\end{array}$ & $\begin{array}{c}-.0511^{*} \\
(.0025)\end{array}$ & $\begin{array}{c}-.0017 * \\
(.0006)\end{array}$ & $\begin{array}{c}-.0025^{*} \\
(.0006)\end{array}$ \\
\hline CAMELS-1 & $\begin{array}{l}.0250^{*} \\
(.0056)\end{array}$ & $\begin{array}{l}.0238^{*} \\
(.0056)\end{array}$ & $\begin{array}{l}.0044^{*} \\
(.0014)\end{array}$ & $\begin{array}{c}.0013 \\
(.0014)\end{array}$ \\
\hline CAPITAL & $\begin{array}{l}-.0297 \\
(.0672)\end{array}$ & $\begin{array}{l}-.0306 \\
(.0672)\end{array}$ & $\begin{array}{c}.0232 \\
(.0165)\end{array}$ & $\begin{array}{c}.0107 \\
(.0163)\end{array}$ \\
\hline RESERVES & $\begin{array}{c}.6465 \\
(.6906)\end{array}$ & $\begin{array}{c}.6831 \\
(.6906)\end{array}$ & $\begin{array}{c}-1.115^{*} \\
(.1699)\end{array}$ & $\begin{array}{l}-.3138 \\
(.1671)\end{array}$ \\
\hline PAST-DUE 90 & $\begin{array}{c}.6325 \\
(.7134)\end{array}$ & $\begin{array}{c}.6787 \\
(.7308)\end{array}$ & $\begin{array}{l}1.018^{*} \\
(.1755)\end{array}$ & $\begin{array}{c}.3147 \\
(.1768)\end{array}$ \\
\hline NONACCRUAL & $\begin{array}{c}.7212 \\
(.5674)\end{array}$ & $\begin{array}{l}.6116 \\
(.5622)\end{array}$ & $\begin{array}{l}1.071^{*} \\
(.1396)\end{array}$ & $\begin{array}{l}.7251^{*} \\
(.1360)\end{array}$ \\
\hline OTHER REAL ESTATE & $\begin{array}{c}-.9510 \\
(1.000)\end{array}$ & $\begin{array}{c}-.3552 \dagger \\
(.9354)\end{array}$ & $\begin{array}{c}.0884 \\
(.2460)\end{array}$ & $\begin{array}{l}1.143^{*} \\
(.2263)\end{array}$ \\
\hline CHARGE-OFFS & $\begin{array}{c}-2.250 \\
(1.413)\end{array}$ & $\begin{array}{c}-2.818 \dagger \\
(1.401)\end{array}$ & $\begin{array}{l}.6974 \dagger \\
(.3476)\end{array}$ & $\begin{array}{c}-3.166^{*} \\
(.3391)\end{array}$ \\
\hline PROVISIONS & $\begin{array}{c}1.519 \\
(1.385)\end{array}$ & $\begin{array}{l}2.719 \dagger \\
(1.350)\end{array}$ & $\begin{array}{l}1.133^{*} \\
(.3407)\end{array}$ & $\begin{array}{l}7.735^{*} \\
(.3268)\end{array}$ \\
\hline INC NOT COLLECTED & $\begin{array}{c}.4369 \\
(.6441)\end{array}$ & $\begin{array}{c}.4260 \\
(.6472)\end{array}$ & $\begin{array}{c}-.2274 \\
(.1584)\end{array}$ & $\begin{array}{c}-.4170^{*} \\
(.1566)\end{array}$ \\
\hline RETURN ON ASSETS & $\begin{array}{l}-.1693 \\
(.2726)\end{array}$ & $\begin{array}{c}-.2445 \\
(.2682)\end{array}$ & $\begin{array}{l}-.1106 \\
(.0671)\end{array}$ & $\begin{array}{l}-.2595^{*} \\
(.0649)\end{array}$ \\
\hline SECURITIES & $\begin{array}{c}.0088 \\
(.0223)\end{array}$ & $\begin{array}{c}.0134 \\
(.0223)\end{array}$ & $\begin{array}{c}-.0215^{*} \\
(.0055)\end{array}$ & $\begin{array}{c}.0036 \\
(.0054)\end{array}$ \\
\hline $\mathrm{CASH}$ & $\begin{array}{c}-.2452^{*} \\
(.0340)\end{array}$ & $\begin{array}{l}-.2422^{*} \\
(.0340)\end{array}$ & $\begin{array}{l}-.0084 \\
(.0084)\end{array}$ & $\begin{array}{c}.0080 \\
(.0082)\end{array}$ \\
\hline LARGE CDs & $\begin{array}{c}.0555 \\
(.0416)\end{array}$ & $\begin{array}{c}.0523 \\
(.0416)\end{array}$ & $\begin{array}{l}.0308^{*} \\
(.0102)\end{array}$ & $\begin{array}{c}.0153 \\
(.0101)\end{array}$ \\
\hline
\end{tabular}

${ }^{\mathrm{a}}$ There are 24,519 observations, 9,643 with $E X A M=1$ and 245 with $R E V I S I O N=1$.

* Significant at the 1-percent level. $\dagger$ Significant at the 5-percent level. 
Table 11: Two-Stage Least Squares Regression Results for REVISION

$(C A M E L S-1=3,4 \text {, or } 5)^{\mathrm{a}}$

\begin{tabular}{|c|c|c|c|c|}
\hline & \multicolumn{2}{|c|}{$E X A M$} & \multicolumn{2}{|c|}{ REVISION } \\
\hline & Original data & Revised data & Original data & Revised data \\
\hline Constant & $\begin{array}{l}1.476^{*} \\
(.2334)\end{array}$ & $\begin{array}{l}1.540^{*} \\
(.2330)\end{array}$ & $\begin{array}{c}-.2809 \\
(.1553)\end{array}$ & $\begin{array}{l}-.2343 \\
(.1517)\end{array}$ \\
\hline FREQUENCY & $\begin{array}{l}-.1720^{*} \\
(.0113)\end{array}$ & $\begin{array}{l}-.1720^{*} \\
(.0113)\end{array}$ & & \\
\hline$E X A M$ & & & $\begin{array}{c}.0507 \\
(.0421)\end{array}$ & $\begin{array}{l}.0824 \dagger \\
(.0412)\end{array}$ \\
\hline SIZE & $\begin{array}{c}-.0325 \dagger \\
(.0158)\end{array}$ & $\begin{array}{c}-.0351 \dagger \\
(.0159)\end{array}$ & $\begin{array}{l}.0247 \dagger \\
(.0103)\end{array}$ & $\begin{array}{l}.0247 \dagger \\
(.0100)\end{array}$ \\
\hline CAMELS-1 & $\begin{array}{l}-.0392^{*} \\
(.0330)\end{array}$ & $\begin{array}{l}-.0485 \\
(.0331)\end{array}$ & $\begin{array}{l}.0631^{*} \\
(.0213)\end{array}$ & $\begin{array}{c}.0228 \\
(.0209)\end{array}$ \\
\hline CAPITAL & $\begin{array}{c}-1.237^{*} \\
(.2772)\end{array}$ & $\begin{array}{c}-1.228^{*} \\
(.2757)\end{array}$ & $\begin{array}{l}-.0765 \\
(.1816)\end{array}$ & $\begin{array}{l}-.0763 \\
(.1764)\end{array}$ \\
\hline RESERVES & $\begin{array}{c}3.181 \\
(2.141)\end{array}$ & $\begin{array}{c}2.859 \\
(2.074)\end{array}$ & $\begin{array}{c}-4.363^{*} \\
(1.386)\end{array}$ & $\begin{array}{c}-1.582 \\
(1.313)\end{array}$ \\
\hline PAST-DUE 90 & $\begin{array}{c}-.3027 \\
(1.326)\end{array}$ & $\begin{array}{c}-.4808 \\
(1.348)\end{array}$ & $\begin{array}{c}1.277 \\
(.8505)\end{array}$ & $\begin{array}{c}-.5873 \\
(.8447)\end{array}$ \\
\hline NONACCRUAL & $\begin{array}{c}-.2676 \\
(1.034)\end{array}$ & $\begin{array}{c}.1281 \\
(1.018)\end{array}$ & $\begin{array}{c}.2786 \\
(.6636)\end{array}$ & $\begin{array}{l}-.7731 \\
(.6387)\end{array}$ \\
\hline OTHER REAL ESTATE & $\begin{array}{c}-1.826 \\
(1.292)\end{array}$ & $\begin{array}{c}-1.949 \\
(1.302)\end{array}$ & $\begin{array}{c}-.2795 \\
(.8342)\end{array}$ & $\begin{array}{c}.4149 \\
(.8224)\end{array}$ \\
\hline CHARGE-OFFS & $\begin{array}{c}-.2369 \\
(2.644)\end{array}$ & $\begin{array}{l}-.2679 \\
(2.601)\end{array}$ & $\begin{array}{c}-.8967 \\
(1.697)\end{array}$ & $\begin{array}{c}-4.429^{*} \\
(1.632)\end{array}$ \\
\hline PROVISIONS & $\begin{array}{c}.1137 \\
(2.188)\end{array}$ & $\begin{array}{c}.5140 \\
(2.211)\end{array}$ & $\begin{array}{c}1.607 \\
(1.404)\end{array}$ & $\begin{array}{l}6.411^{*} \\
(1.387)\end{array}$ \\
\hline INC NOT COLLECTED & $\begin{array}{c}3.141 \\
(2.935)\end{array}$ & $\begin{array}{c}2.771 \\
(2.946)\end{array}$ & $\begin{array}{c}-2.185 \\
(1.875)\end{array}$ & $\begin{array}{c}-1.017 \\
(1.841)\end{array}$ \\
\hline RETURN ON ASSETS & $\begin{array}{c}-.2863 \\
(1.057)\end{array}$ & $\begin{array}{c}-.1022 \\
(1.028)\end{array}$ & $\begin{array}{l}-1.072 \\
(.6780)\end{array}$ & $\begin{array}{c}-2.746^{*} \\
(.6448)\end{array}$ \\
\hline SECURITIES & $\begin{array}{l}.2805 \dagger \\
(.1264)\end{array}$ & $\begin{array}{c}.2448 \\
(.1249)\end{array}$ & $\begin{array}{c}-.2467^{*} \\
(.0820)\end{array}$ & $\begin{array}{c}-.1949 \dagger \\
(.0792)\end{array}$ \\
\hline $\mathrm{CASH}$ & $\begin{array}{c}.1241 \\
(.1720)\end{array}$ & $\begin{array}{c}.1138 \\
(.1728)\end{array}$ & $\begin{array}{l}-.0221 \\
(.1106)\end{array}$ & $\begin{array}{c}.0653 \\
(.1087)\end{array}$ \\
\hline LARGE CDs & $\begin{array}{l}-.1829 \\
(.1759)\end{array}$ & $\begin{array}{l}-.1911 \\
(.1754)\end{array}$ & $\begin{array}{l}-.0399 \\
(.1134)\end{array}$ & $\begin{array}{l}-.0194 \\
(.1105)\end{array}$ \\
\hline
\end{tabular}

${ }^{\mathrm{a}}$ There are 995 observations, 563 with $E X A M=1$ and 91 with $R E V I S I O N=1$.

* Significant at the 1-percent level. $\dagger$ Significant at the 5-percent level. 